\title{
Late Miocene to present day structural development of the Polish segment of the Outer Carpathians
}

\author{
W. Zuchiewicz ${ }^{1}$, A. K. Tokarski ${ }^{2}$, M. Jarosiński ${ }^{3}$, and E. Márton ${ }^{4}$ \\ ${ }^{1}$ Jagiellonian University, Institute of Geological Sciences, Oleandry 2A, PL-30063 Kraków, Poland \\ ${ }^{2}$ Institute of Geological Sciences,Polish Academy of Sciences, Research Centre in Kraków, Senacka 1, PL-31002 Kraków, \\ Poland \\ ${ }^{3}$ Polish Geological Institute, Rakowiecka 4, PL-00975 Warszawa, Poland \\ ${ }^{4}$ Eötvös Lorand Geophysical Institute, Columbus ut. 17-23, H-1145 Budapest, Hungary
}

Received: 2 May 2000 - Accepted: 28 January 2001

\begin{abstract}
This paper presents a few pieces of evidence on neotectonic structural evolution of the Polish segment of the Outer Carpathians. During the Late Neogene, structural development was largely controlled by normal faulting and block uplift. However, there are also indications of compressional stress setting, at least during the Pliocene and particularly within the medial and eastern parts of the belt. In the Quaternary, in turn, structural development has been mainly controlled by compressional stress arrangement, with $\sigma_{1}$ orientated roughly perpendicular to the belt. The PlioceneQuaternary tectonic mobility of the Polish Outer Carpathians has been relatively weak and mostly of thin-skinned character. Normal faults were formed on the margins of intramontane basins and in the western part of the belt. Rates of uplift of individual structures were variable and the amount of uplift was the greatest in the Late Pliocene and Early Quaternary times. Geomorphologically-detected zones of uplift are relatively narrow and arranged subparallel or under small angle in respect to the strike of principal thrusts and frontal parts of large slices. Such an arrangement is interpreted as resulting from the steepening of frontal thrusts due to horizontal compression within the overthrust flysch nappes. This hypothesis is confirmed by the results of recent break-out and GPS studies, as well as by focal solutions of some Outer Carpathian earthquakes.
\end{abstract}

\section{Introduction}

This paper presents an insight into structural development in the Polish segment of the Outer Carpathians since the completion of Tertiary subduction until Present. The timing of this completion is poorly constrained and the existing pieces of evidence on structural development are very scarce.

Correspondence to: W. Zuchiewicz (witold@ing.uj.edu.pl)
The time-span considered is frequently referred to as "neotectonic period". From among different definitions of neotectonics, we are inclined to accept that by Şengör et al. (1985): ... "the time that elapsed since the last major whole-scale tectonic reorganization".

\section{Geological setting}

The Polish segment of the Outer Carpathians is a northverging thrust-and-fold belt comprising several nappes (Fig. 1) which are largely composed of Lower Cretaceous to Lower Miocene flysch strata. In intramontane basins, unfolded Neogene to Recent strata unconformably overlie the Outer Carpathian nappes.

To the north, the Polish segment of the Outer Carpathians (Figs. 1,2) is thrust over the Carpathian Foredeep which is filled by Miocene strata mostly of Badenian, Sarmatian, and also Pannonian age (cf. Oszczypko, 1998; Wójcik et al., 1999). Close to the Carpathian frontal thrust, this Miocene complex is tightly folded and cut by north-verging thrusts. This folded zone, called the Zgłobice Unit (Kotlarczyk, 1985), is up to $10 \mathrm{~km}$ wide. To the south, the Outer Carpathians are in contact along subvertical faults with the Pieniny Klippen Belt (Birkenmajer, 1985).

The Miocene strata of the Carpathian Foredeep unconformably overlie the Precambrian to Mesozoic complexes of the European Platform (Oszczypko et al., 1989). In the study area, the European Platform is subdivided into the Upper Silesian block to the west and the Małopolska block to the east (Figs. 1, 2, 15). These two blocks are separated by the Kraków-Lubliniec fault zone, the locus of repeated strikeslip movements that have been active since the Palaeozoic up to Quaternary times (Żaba, 1999, and references therein). 


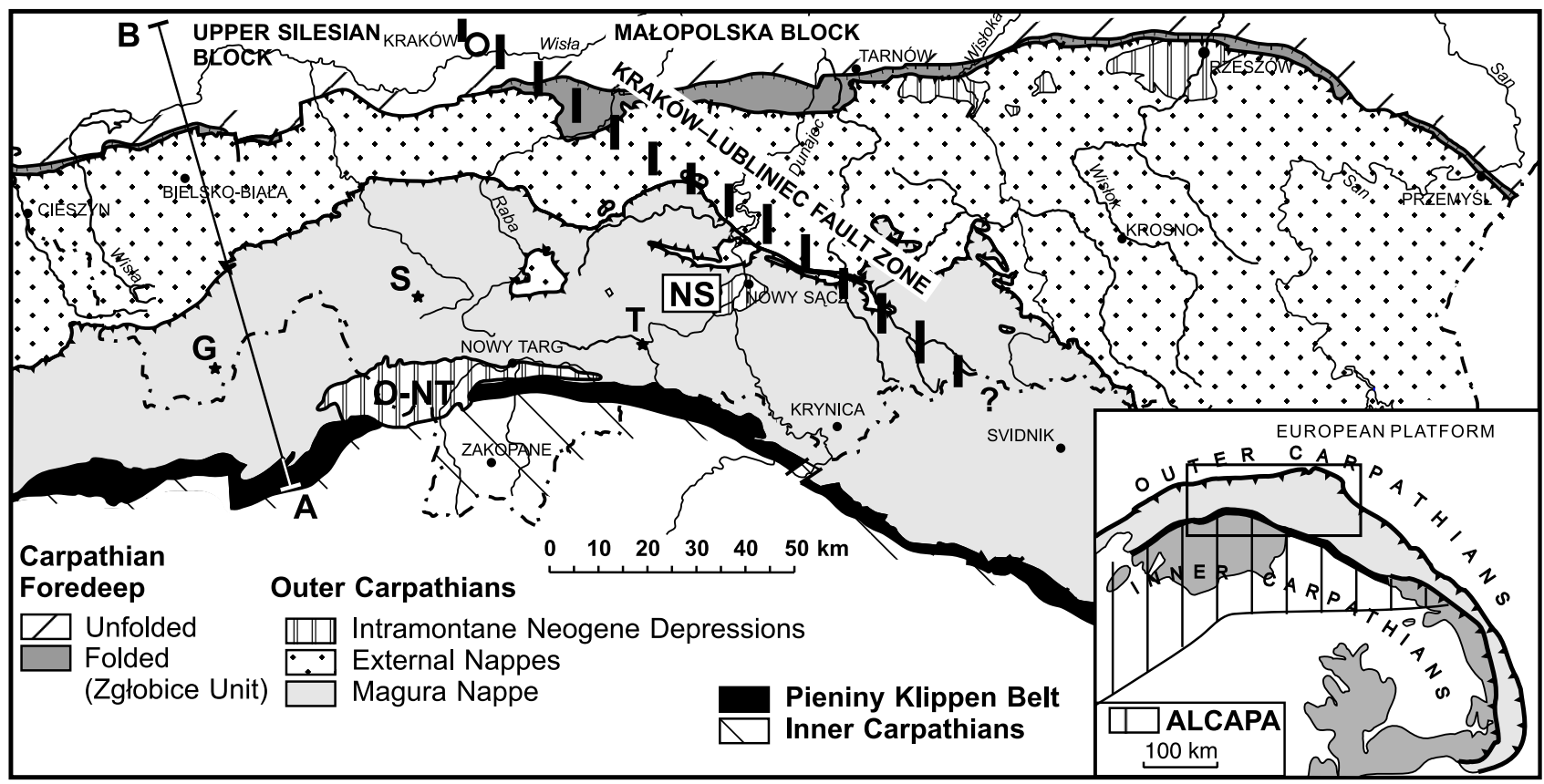

Fig. 1. Polish segment of the Carpathian arc (geology after Żytko et al., 1989; supplemented). Intramontane basins: O-NT = Orava - Nowy Targ, NS = Nowy Sạcz; localities mentioned in the text: $\mathrm{G}=$ Glinka, S = Sidzina, $\mathrm{T}=$ Tylmanowa. Note that the Kraków-Lubliniec fault zone is located in the Carpathians' basement.

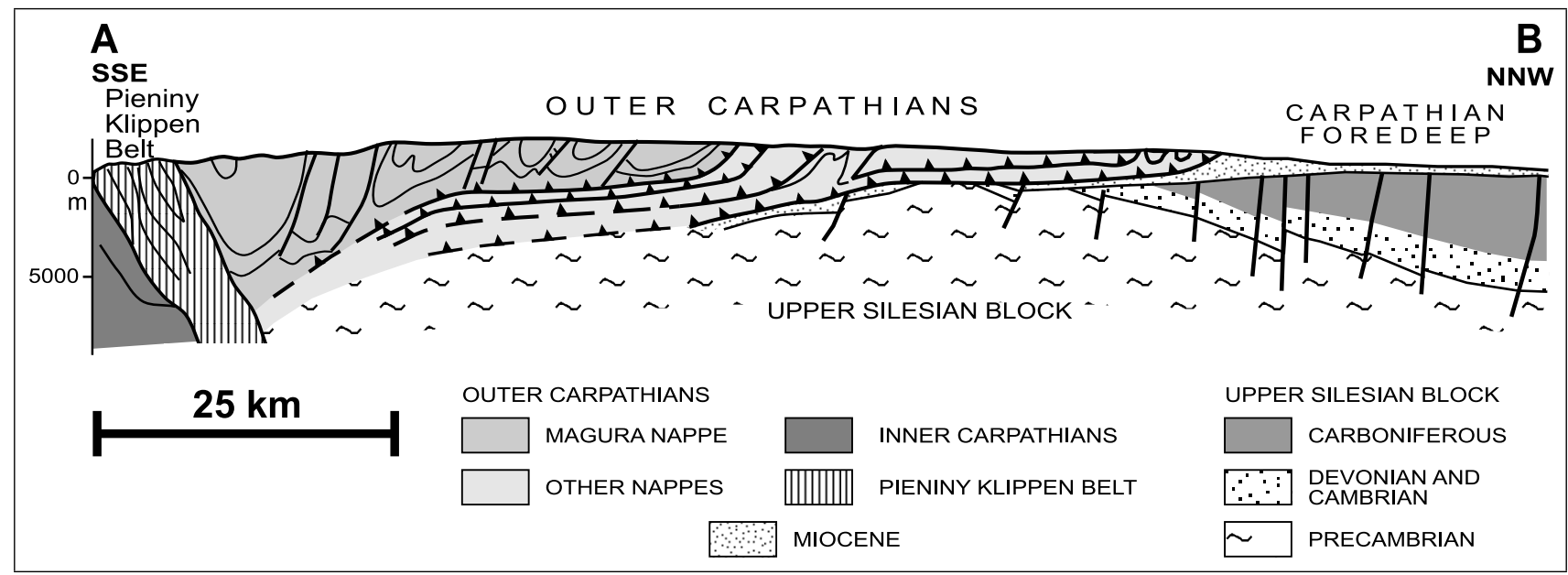

Fig. 2. Schematic cross-section (after Żytko et al., 1989). For location see Fig. 1.

\section{Pre-neotectonic history}

The main structural elements of the Polish segment of the Outer Carpathians (Fig. 1) were formed during Tertiary times when the belt was locus of the southward-directed subduction of the southern margin of the European Platform below the ALCAPA unit (sensu Csontos et al., 1992; Csontos 1995; Oszczypko, 1998; Fodor et al., 1999). The subduction-related synsedimentary shortening (Tokarski and Świerczewska, 1998, and references therein; Żytko, 1999; cf. also Żytko, 1977) resulted in successive incorporations of the Outer Carpathian nappes and the Zgłobice unit into the subduction-related accretionary prism (cf. Fodor et al., 1999). These incorporations started during Eocene times in the Magura nappe (Świerczewska and Tokarski, 1998) and terminated after the Badenian in the Zgłobice unit (Oszczypko, 1996, 1998, and references therein).

Results of recent structural analysis (Decker et al., 1997, 1999) performed at over 120 exposures suggest that the accretion-related shortening might have been at first, since at least the Paleocene (Kopciowski et al., 1999), directed towards the NW (in the present-day coordinates) (Fig. 3) and afterwards apparently rotated towards the NE (cf. Aleksandrowski, 1985; Decker et al., 1997). Results of recent 


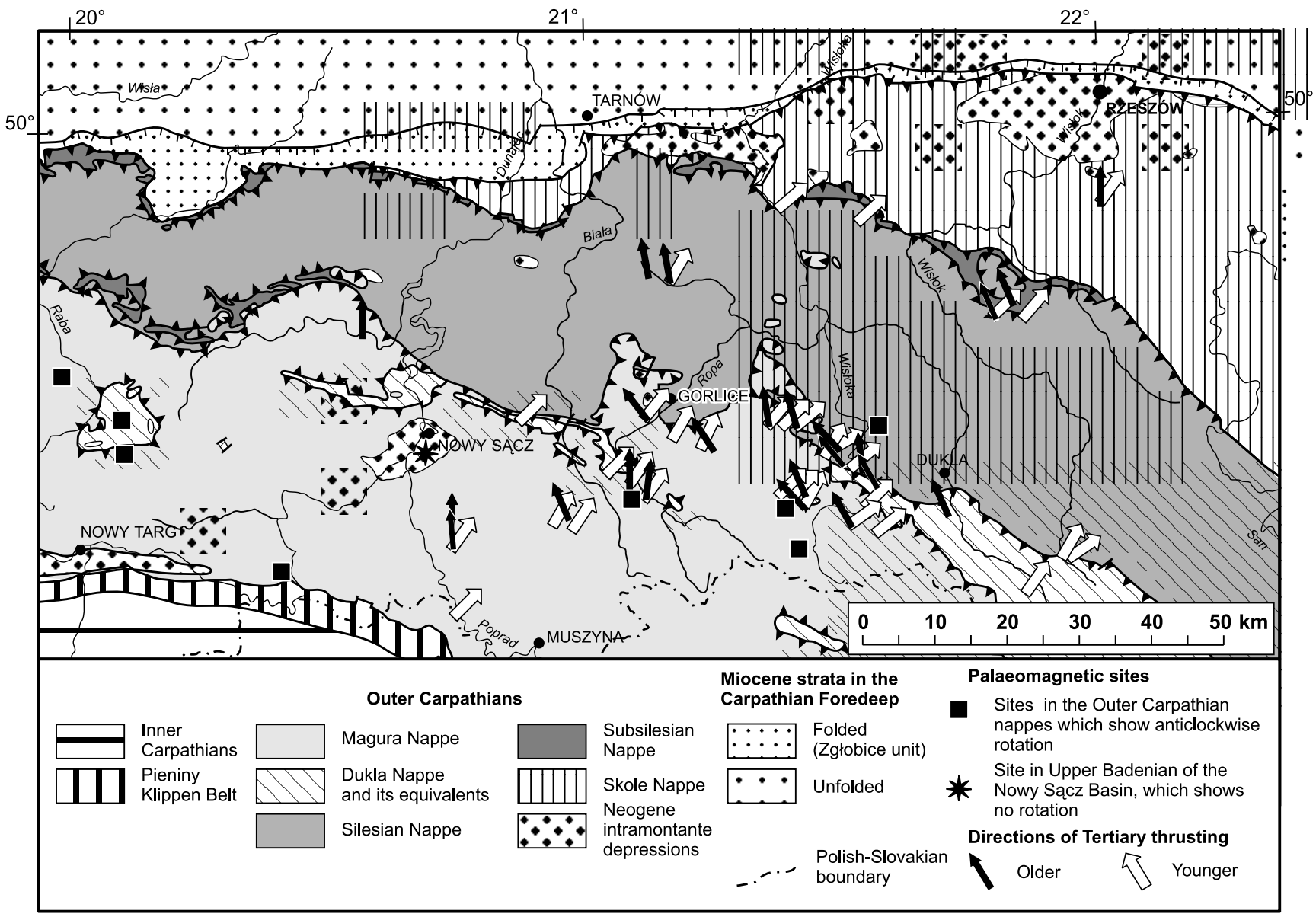

Fig. 3. Medial-eastern part of the Polish segment of the Carpathian arc (geology after Żytko et al., 1989; supplemented) showing results of structural analysis (after Decker et al., 1999) and locations of palaeomagnetic sites within the Outer Carpathians (after unpublished data by Márton and Tokarski).

palaeomagnetic research performed at 58 localities appear to indicate that the apparent clockwise rotation of the regional stress field was probably due to the large-scale post-early Badenian anticlockwise rigid body rotations observed in the Polish segment of the Inner (Márton et al., 1999a) and Outer Carpathians (Márton et al., 1999b) (Fig. 3), as well as within the Zgłobice unit (Márton et al., 1999c). The results from the upper Badenian strata (Oszczypko et al., 1992) of the intramontane Nowy Sacz Basin show that the anticlockwise rotation could have been completed before the late Badenian, at least in that part of the Outer Carpathians. The data from the Slovak and Hungarian parts of the Inner Carpathians show that the Neogene anticlockwise rotation took place there in two or three successive steps (Kovač and Márton, 1998, and references therein). We believe that the process of the rotation could have been similar within the Polish segment of the Carpathians. However, so far we have not enough data to check this hypothesis.

The age of termination of the accretion-related shortening has been considered to be younging eastwards along the strike of the Carpathians (cf. Uhlig, 1903; Sawicki, 1909; Alexandrowicz, 1964): from $15 \mathrm{Ma}$ at the western- most part of the Polish segment, until $12 \mathrm{Ma}$ at the easternmost part of the segment (Nemčok et al., 1998, and references therein). This interpretation stems from the age of the youngest Miocene strata in the Carpathian Foredeep that are thrust over by the Carpathians. However, recent discovery of the Pannonian strata overthrust by the Outer Carpathian nappes in the western part of the Polish segment of the belt (Wójcik and Jugowiec, 1998; Wójcik et al., 1999) appears to contradict this conjecture and implies that the final episode of thrusting must have occurred after the Pannonian.

\section{Late Miocene - Quaternary structural history}

The bulk of evidence for the structural development during this period comes from the Outer Carpathian nappes. This is supplemented by the results of observations within intramontane basins.

Within the Outer Carpathian nappes, the structures resulting from the accretion-related shortening are commonly overprinted by normal faults (Decker et al., 1997, 1999; Rubinkiewicz, 2000). These faults (Fig. 4), which appear 
(A)

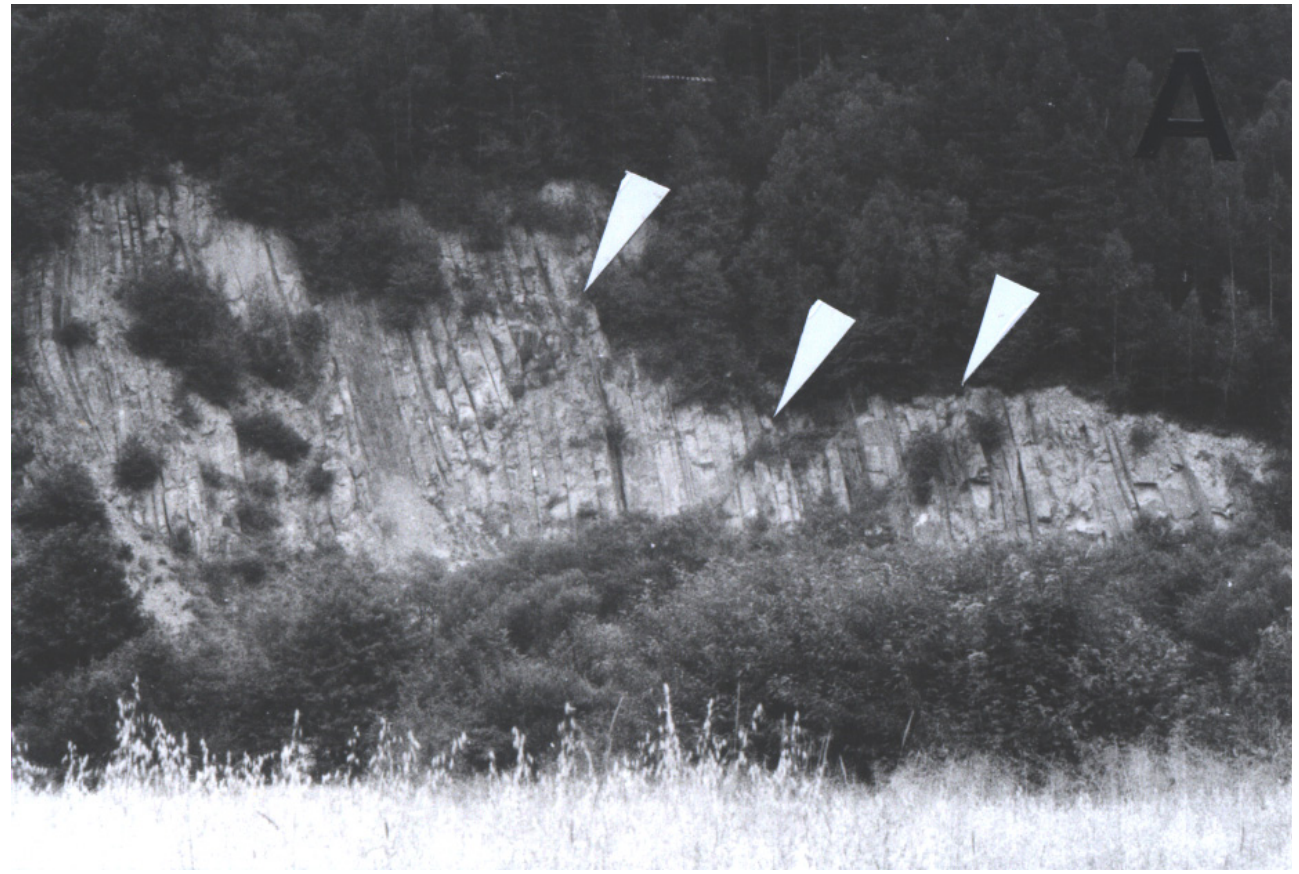

(B)

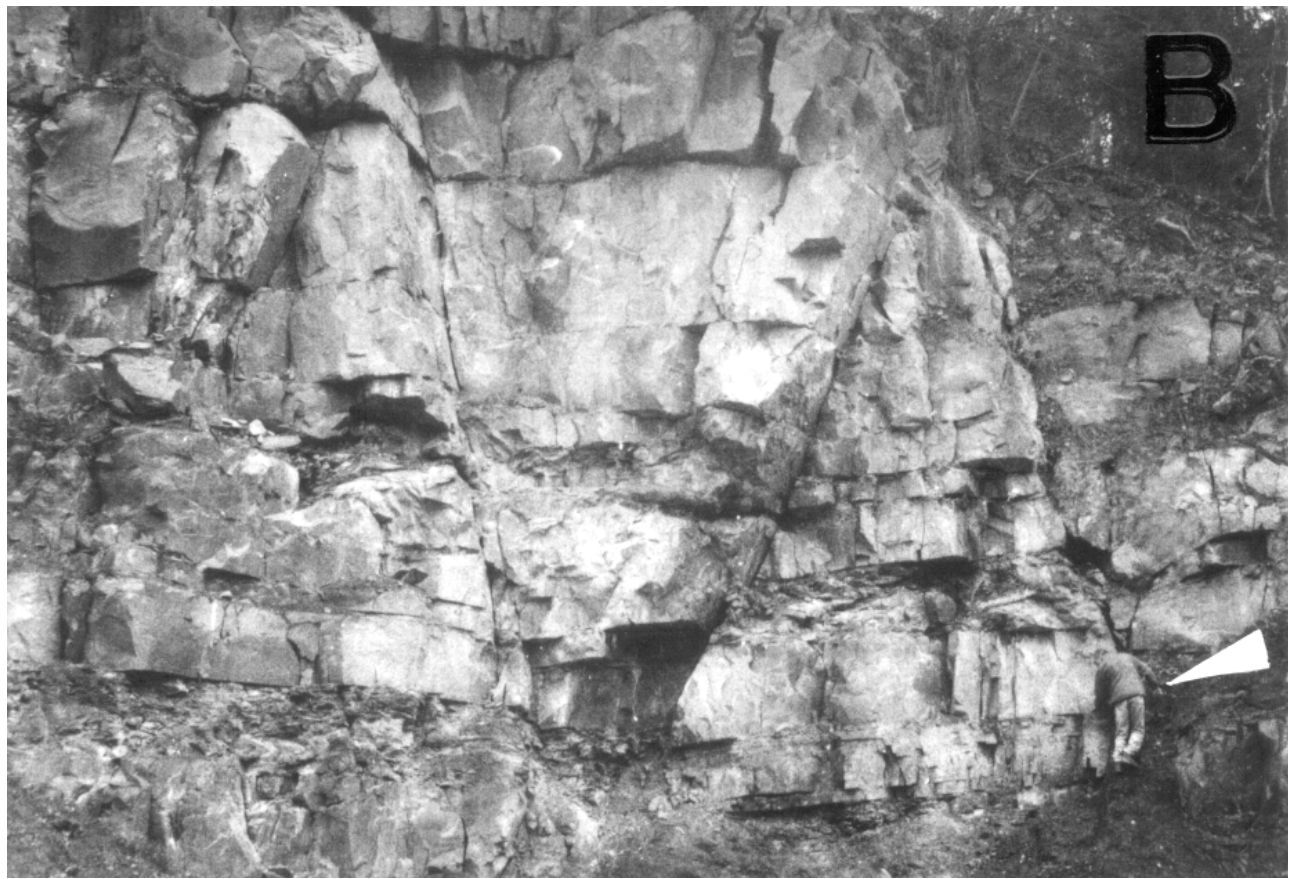

Fig. 4. Normal faults at Sidzina (A) and Glinka (B): A - normal faults (arrowed) cutting subvertically dipping strata, the exposure is $20 \mathrm{~m}$ tall; B - tectonic graben, man (arrowed) for scale. For location see Fig. 1.

to be the youngest tectonic features affecting the nappes, are widespread throughout the whole Polish segment of the Outer Carpathians. At particular exposures, populations of the discussed normal faults were formed due to either N-S or E-W extension (Fig. 5). It is still uncertain whether the faulting took place during successive phases of differentlyorientated extension or during one or more phases of multidirectional extension. The age of faulting is also difficult to estimate; its formation most probably postdated the last episode of thrusting that occurred after the Pannonian in the 

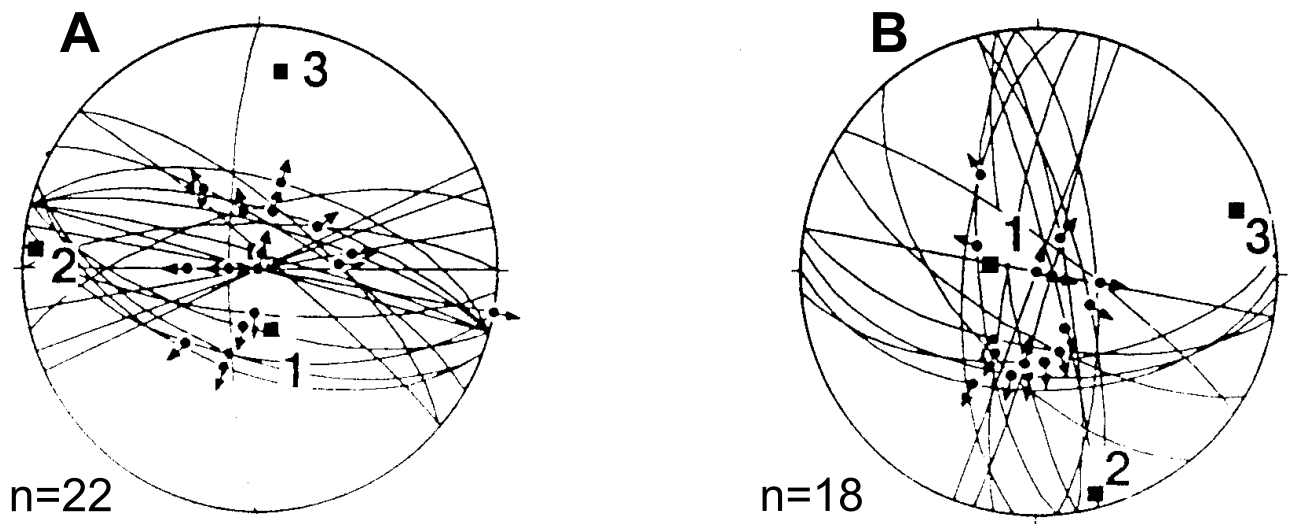

Fig. 5. Plots of normal faults at Glinka (A) and Tylmanowa (B), showing orientation of extension. For location see Fig. 1. $1,2,3-\sigma_{1}, \sigma_{2}, \sigma_{3}$

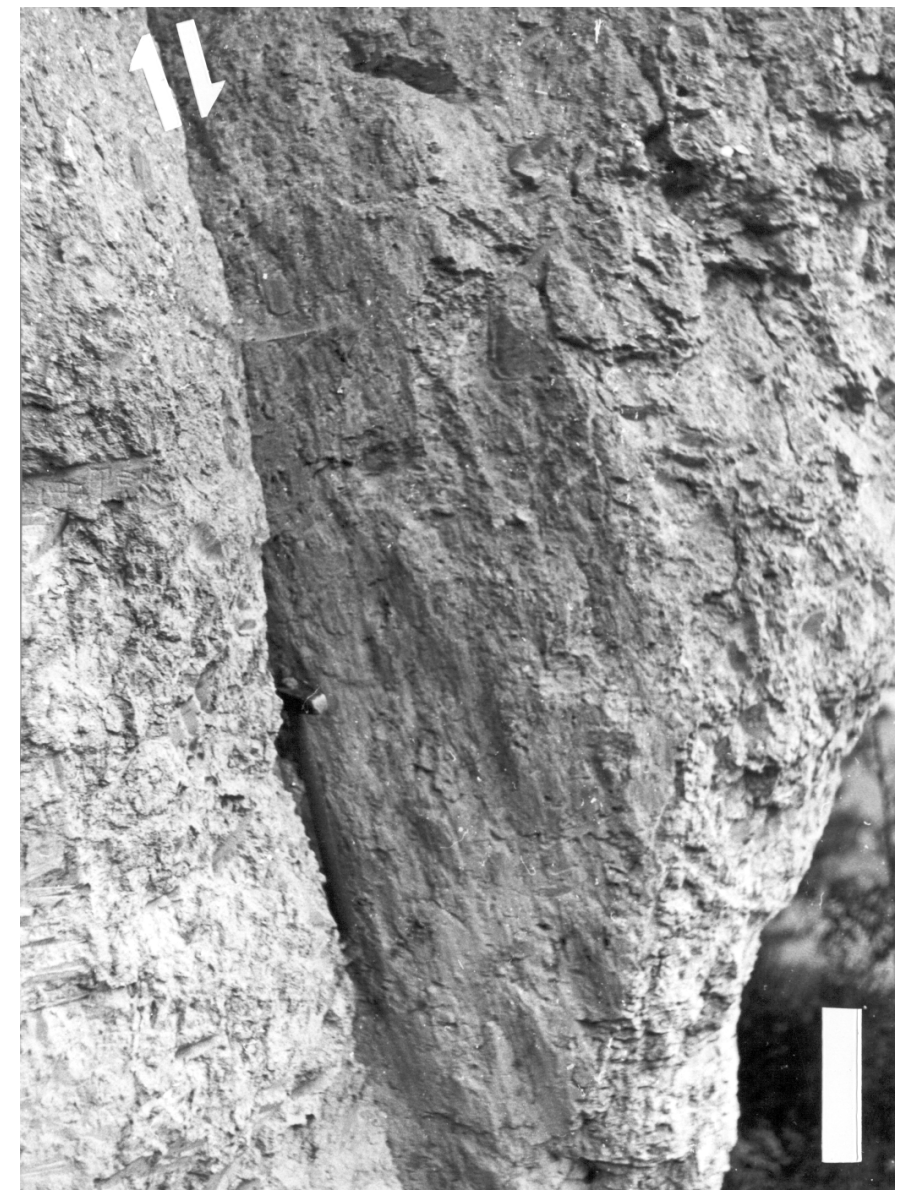

Fig. 6. Normal fault cutting Quaternary loessial loams in the Nowy Sạcz intramontane basin. Scale bar is $20 \mathrm{~cm}$ long. For location see Fig. 1.

marginal part of the Outer Carpathians (cf. Oszczypko and Tomaś, 1985). Alternatively, the onset of the normal faulting could have been diachronous, younging outwards across the Outer Carpathians.

The Orava-Nowy Targ intramontane basin (Fig. 1) is a W-E trending tectonic graben bordered to the south and north by sets of normal faults, with throws up to few hun- dred metres for each set (Pomianowski, 1995, and references therein). The faulting started during the Late Miocene (Pomianowski, 1995) and at least some of the faults were still active during Quaternary times (cf. Niedzielski, 1971; Baumgart-Kotarba, 1996). The Quaternary normal faulting took place also in the Nowy Sacz intramontane basin (Tokarski, 1978), where loessial loams of the penultimate 

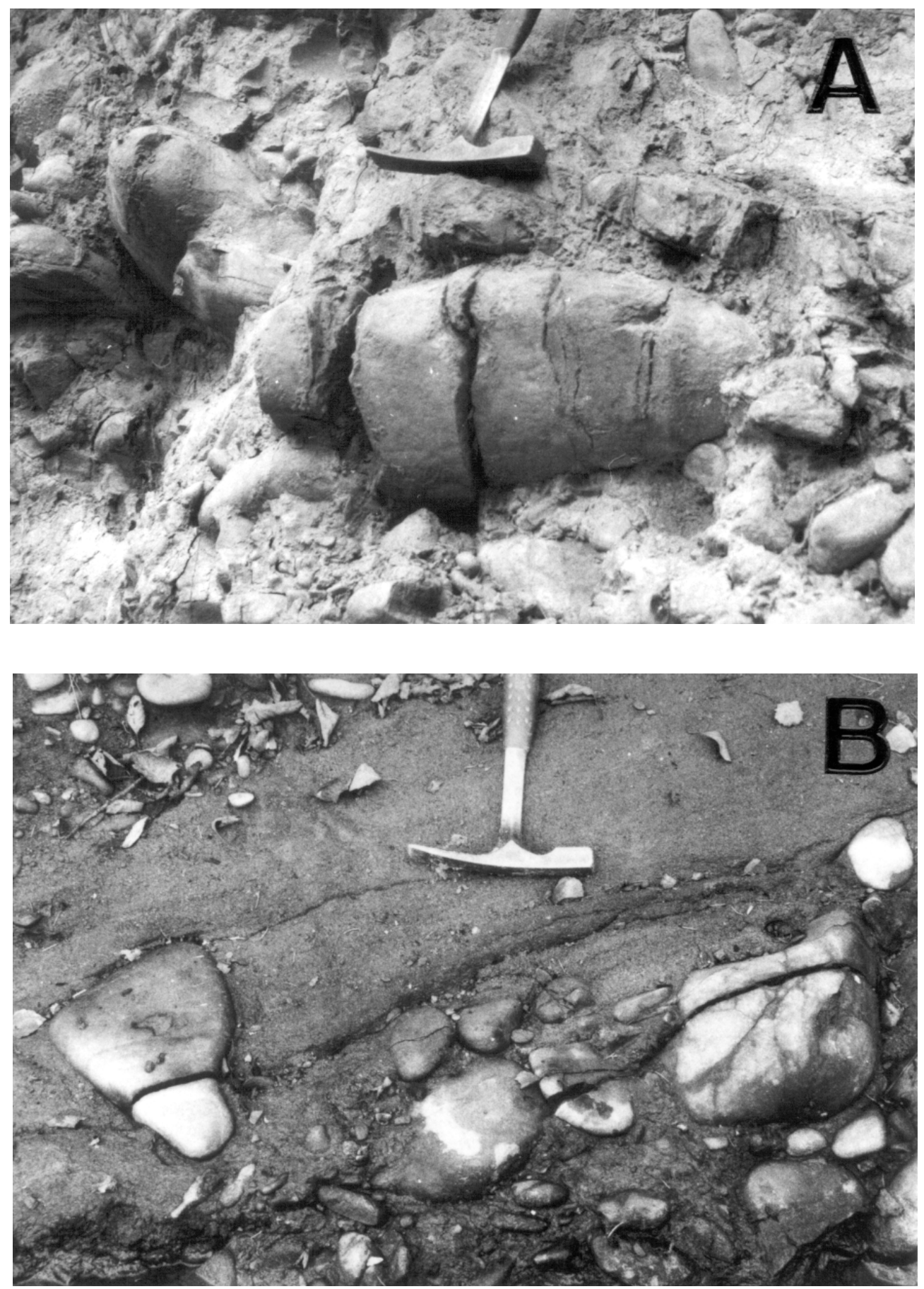

Fig. 7. Fractured clasts ((A), $(\mathbf{B})$ in the Domański Wierch conglomerates (Orava - Nowy Targ intramontane basin). Note that fractures at B are oriented independently of the clast shape. For location see Fig. 1.

glacial stage are cut by a normal fault (Fig. 6).

The other examples of Middle through Late Quaternary normal faulting, though documented less convincingly, come from the Beskid Żywiecki Mts. (Wójcik, 1989, and references therein) and southern part of the Jasło-Sanok Depression (Zuchiewicz, 1987; cf. also Fig. 11).

The Domański Wierch conglomerates form an intercalation within the infill of the Orava-Nowy Targ Basin
(Fig. 1). These poorly-cemented conglomerates are Sarmatian to Pliocene in age (Zastawniak, 1972; Sikora and Wieser, 1974; Oszast and Stuchlik, 1977; Birkenmajer, 1979). Sandstone and limestone clasts within the conglomerates are commonly fractured (Tokarski and Zuchiewicz, 1998; Kukulak, 1999; cf. also Fig. 7). Most of the fractures are subvertical and strike irrespectively of the clast shape and of the present-day topography. The fractures show a well- con- 

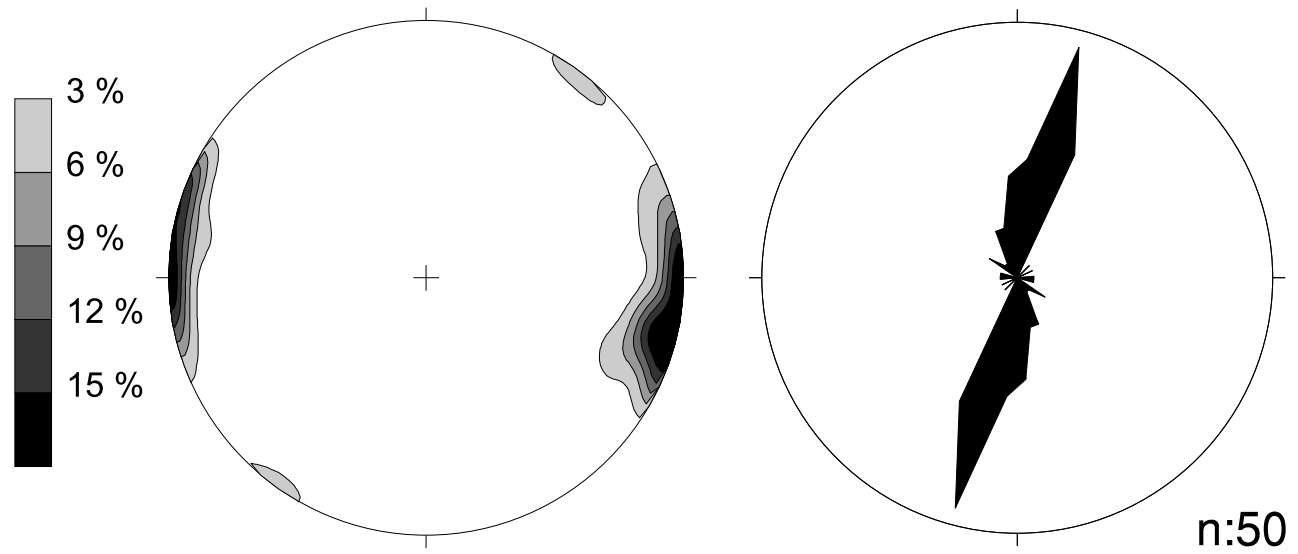

Fig. 8. Lower hemisphere plot and rose-diagram of fractures cutting clasts of the Domański Wierch conglomerates. For location see Fig. 1.

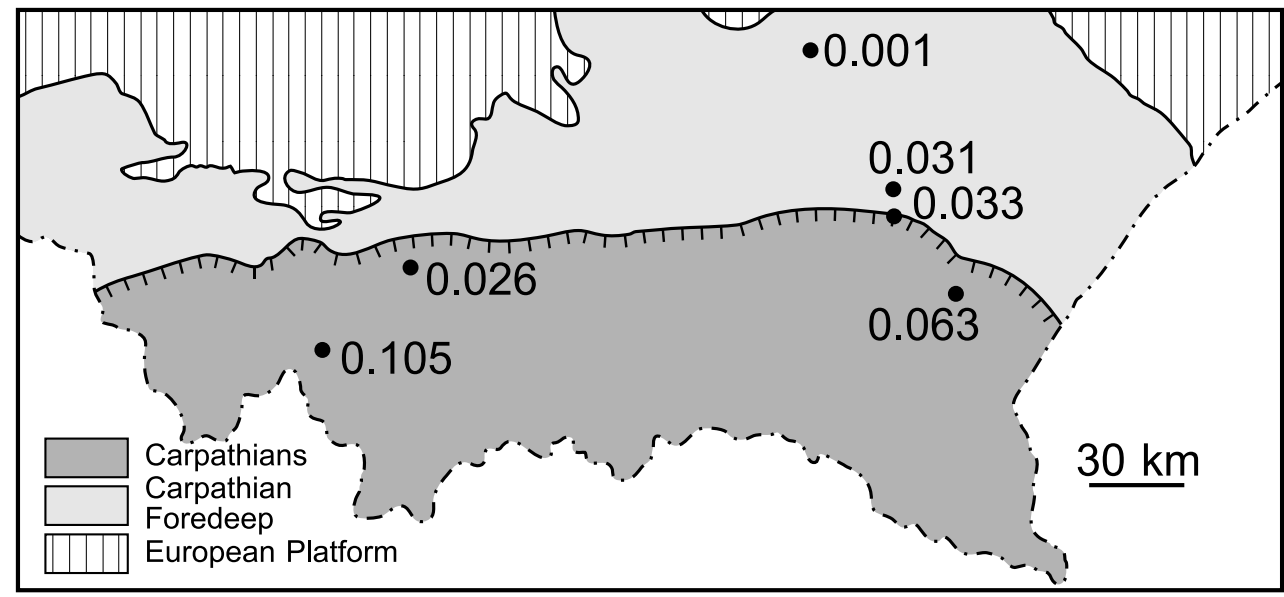

Fig. 9. Long-term isostatic uplift rates ( $\mathrm{mm} / \mathrm{yr}$ ) during the past 10 million years, calculated for some wells in the Outer Carpathians and Carpathian Foredeep (based on data provided by Oszczypko, 1996).

strained maximum orientated NNE (Fig. 8). In our interpretation (Tokarski and Zuchiewicz, 1998), the fractures were formed due to regional strike-slip stress field in which $\sigma_{1}$ was orientated NNE.

The presented pieces of evidence show that after completion of the Tertiary subduction, structural development of the Polish segment of the Outer Carpathians took place in extensional stress regime. Data from the Orava-Nowy Targ and Nowy Sącz intramontane basins (normal faults) imply that the extension lasted there until Quaternary times. Fractured pebbles in the Orava Basin could indicate that the extension was at least locally replaced by a single compressional episode.

\section{Pliocene-Quaternary geomorphological history}

Conventional geomorphic studies aiming at the reconstruction of long-term landform development in the Polish Outer Carpathians have dealt with gross features of the topography, including ridge and valley patterns, the number, origin and age of planation surfaces, as well as the history of fluvial changes, aided by palaeogeographic reconstructions (cf. Starkel, 1972; Henkiel, 1977-78; Zuchiewicz, 1995, and references therein).

\subsection{Planation surfaces and post-orogenic uplift}

The concept of three Pliocene and one early Quaternary planation surfaces, preserved upon bedrock of variable resistance and deformed during a few orogenic pulses, has been dealt with by numerous authors until the late 1980 s (cf. Starkel, 1972; Zuchiewicz, 1984; Klimaszewski, 1988; and discussion therein). However, the lack of correlative deposits makes the precise dating of planation episodes impossible; therefore, the rates of uplift approximated by those of downcutting of planation surfaces or inferred from different estimates of Neogene denudation, appear to be poorly constrained.

The amount of uplift of the medial segment of the Polish Outer Carpathians during Late Neogene and Quaternary times, approximated by the size of erosional dissection of 

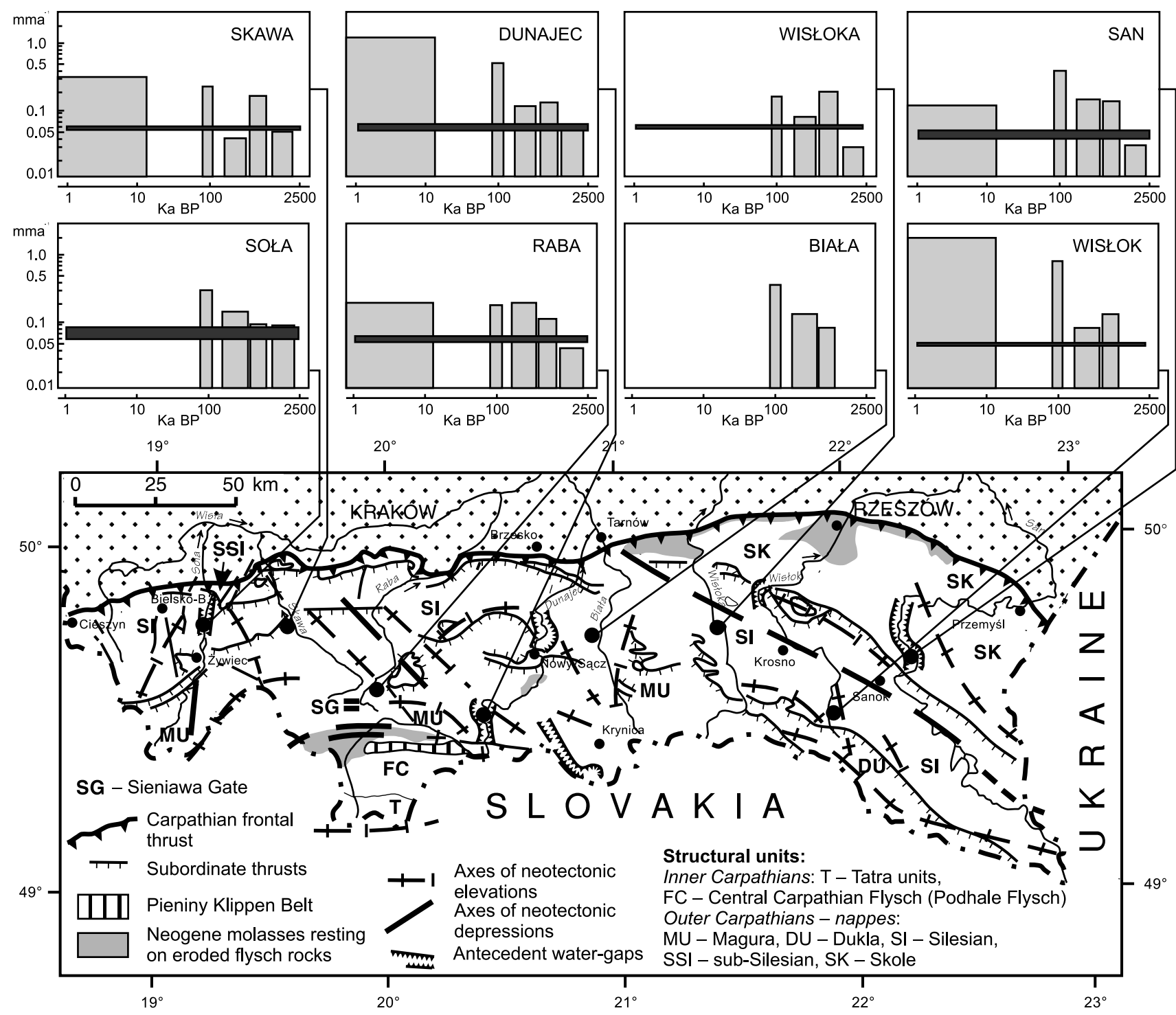

Fig. 10. Neotectonic sketch of the Polish Carpathians (based on Zuchiewicz, 1998). Diagrams portray rates of Quaternary downcutting of straths in those segments of the Polish Carpathian valleys which dissect neotectonically uplifted structures. Solid lines denote average rates of downcutting throughout the Quaternary.

different erosional surfaces, ranged from 150 to $900 \mathrm{~m}$, averaging at ca. $300 \mathrm{~m}$ (Zuchiewicz, 1984, 1991). These figures conform well with the results of seismostratigraphic studies that clearly indicate a minimum of $>200 \mathrm{~m}$ rebound of the lithosphere during the post-late Badenian times (Krzywiec and Zuchiewicz, 1993).

More reliable results are provided by analyses of the minimum size of post-tectonic, isostatic uplift during the past 10 to 11 million years that has been calculated for ca. $1 \mathrm{~km}$ in the West Beskidy Mts. to some 260-360 $\mathrm{m}$ in the Carpathian Foothills (Oszczypko, 1996), the maximum rate of uplift being $0.1 \mathrm{~mm} / \mathrm{yr}$ (Figs. 9, 13). Less convincing are different estimations of the amount of denudation, based on reconstructions of the hypothetical position of palaeo-summit surface in the eastern segment of the Polish Outer Carpathians (4-
$5 \mathrm{~km}$; Kuśmierek, 1990), analyses of the degree of diagenesis (Kotulova et al., 1998), fluid inclusion (Hurai et al., 2000) or compaction studies of overthrust flysch strata and underlying molasses (Oszczypko et al., 1993). Recent studies indicate that the generally modest Bouguer gravity anomalies point to nonisostatic processes causing the postflexural uplift, ranging from $250 \mathrm{~m}$ to $550 \mathrm{~m}$ (Zoetemeijer et al., 1999). Reliable estimates will only be provided by fission track studies.

\subsection{Structural control on landforms and differentiated Qua- ternary uplift}

Structurally-controlled landforms have been either mapped or inferred from the analysis of morphometric maps and statistical modelling of the topography (Fig. 10).

Morphological manifestations of Quaternary tectonic ac- 


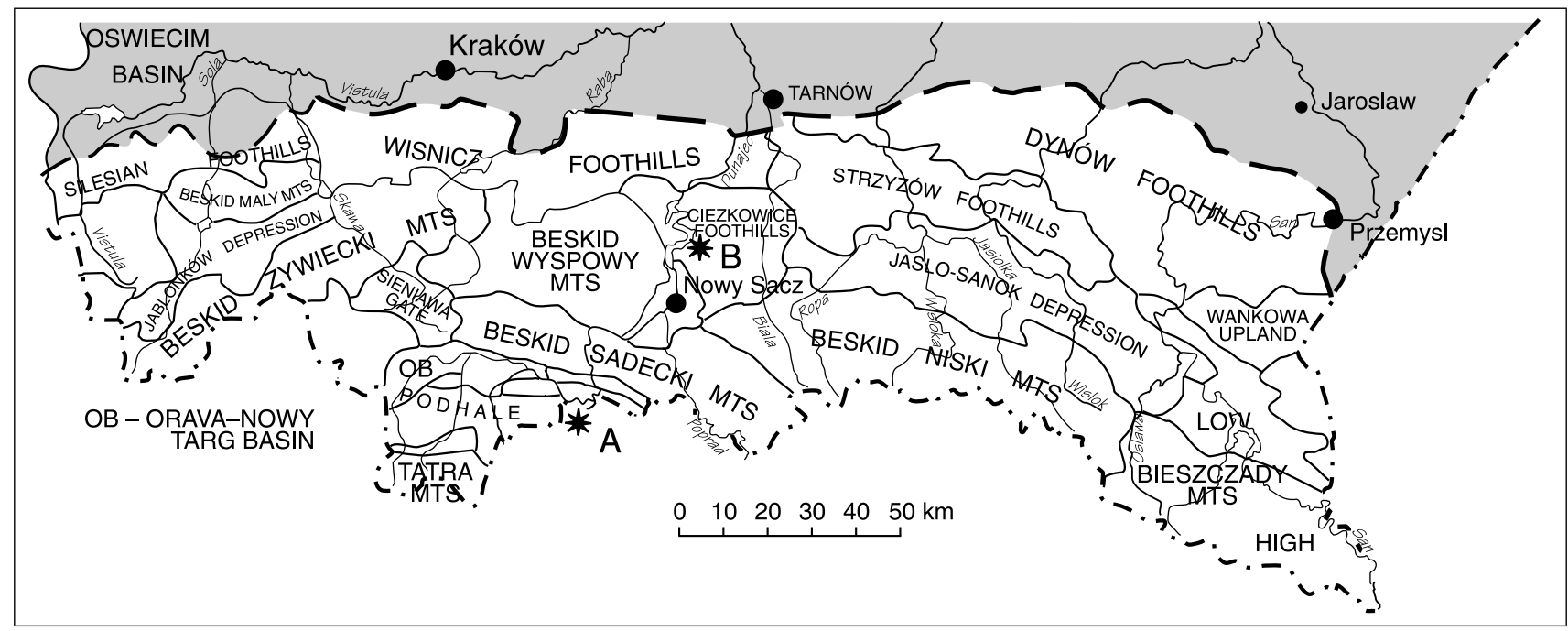

Fig. 11. Geomorphological subdivision of the Polish Carpathians (based on Starkel, 1991; modified). OB = Orava - Nowy Targ Basin; A/B = medial segment of the Dunajec River valley, whose longitudinal profile is shown in Fig. 12.

tivity include: disturbed longitudinal profiles of strath terraces (Starkel, 1972; Zuchiewicz, 1991, 1995) of all main Outer Carpathian rivers, frequently indicating Recent reactivation of the pre-existing fault zones (cf. Figs. 11, 12), incomplete sequences of alluvia in the Jasło-Sanok Depression (Starkel, 1985; Zuchiewicz, 1987), convex-upward slope profiles in strongly elevated regions, mainly in the Beskid Sądecki Mts. (Starkel, 1972), young changes in the drainage pattern in the Jasło-Sanok Depression and the Strzyżów Foothills (Gerlach et al., 1985; Zuchiewicz, 1987), tilting of Upper Pleistocene lacustrine sediments in the southern part of the Jasło-Sanok Depression (Koszarski and Koszarski, 1985), and some examples of young subsidence in the intramontane Orava - Nowy Targ and Nowy Sacz basins (Baumgart-Kotarba, 1991-92, 1996; Zuchiewicz, 1984).

In the western and medial segments of the Polish Outer Carpathians, predominance of strongly dissected areas results mainly from Pliocene-Quaternary uplift (Starkel, 1972; Zuchiewicz, 1995, and references therein). For instance, a large morphological depression located north of the Orawa Basin, the Sieniawa Gate (cf. Figs. 10, 11), is composed of thick-bedded flysch strata of the Magura nappe, which are exactly as resistant as those which build the neighbouring, strongly elevated and dissected physiographic units to the west (Beskid Żywiecki Mts.) and east (Beskid Sądecki Mts.; cf. Fig. 11).

Conventional geomorphological analyses focusing on structural landforms and disturbances recorded in deformed longitudinal profiles of strath terraces lead to a conclusion that the Pliocene-Quaternary differential vertical movements have resulted in the formation of several elevated and subsided structures orientated roughly parallel to the structural grain of the area (Figs. 10, 11), the maximum size of Quaternary uplift attaining some $150 \mathrm{~m}$ in the Beskid Sądecki Mts., and in other regions varying from 50 to $100 \mathrm{~m}$ (cf. Starkel, 1980; Zuchiewicz, 1984, 1995).

\subsection{Rates of river downcutting and the periodicity of uplift}

Rates of river downcutting are one of necessary tools for understanding rates of erosion, landform evolution, and tectonic uplift. Variations in downcutting rates along the valley's profile help to reconstruct the spatial pattern of uplift (cf. Schumm, 1986; Burbank et al. 1996).

Valleys of the main Outer Carpathian rivers bear 8 to 9 terrace steps of Quaternary age (Zuchiewicz, 1984, 1991). Most of Pleistocene terraces are strath or complex- response terraces (cf. Bull, 1990); the Weichselian and Holocene steps are usually cut- and-fill terraces, except for those which are located in the neotectonically elevated structures and are characterised by the presence of young straths (Starkel, 1972; Zuchiewicz, 1984, 1998; cf. also Fig. 12).

Longitudinal profiles of individual strath terraces frequently show divergence, convergence or tilting that can be indicative of young tectonic control (Zuchiewicz, 1987, 1991, 1995; Henkiel et al., 1988, Wójcik, 1989). Moreover, the size and rate of dissection of straths of comparable age are different in different morphotectonic units; a feature pointing to variable pattern of Quaternary uplift (cf. Figs. 10, 13). This applies particularly to neotectonically uplifted regions dissected by antecedent watergaps of the main Outer Carpathian rivers (Fig. 10). Rates of river downcutting result mainly from climatic changes throughout the glacial-interglacial cycles (cf. discussion in Starkel, 1985, 1996 and Zuchiewicz, 1995), but their spatial differentiation throughout a relatively small area appears to be tectonically, and not climatically- controlled. Figures 10 and 13 portray variable rates of fluvial downcutting of strath terraces within those valley reaches which truncate geomorphic units uplifted in Plio-Quaternary times (cf. also Starkel, 1972; Zuchiewicz, 1998). These figures differ from unit to unit, although three episodes of increased downcutting rates can be distinguished in the Polish Outer 


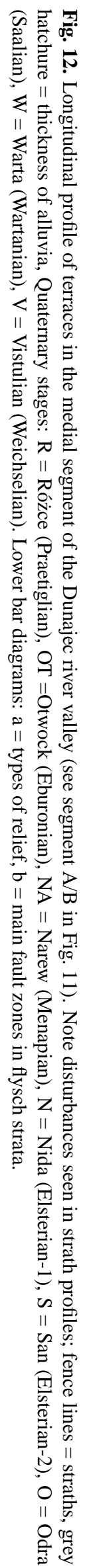

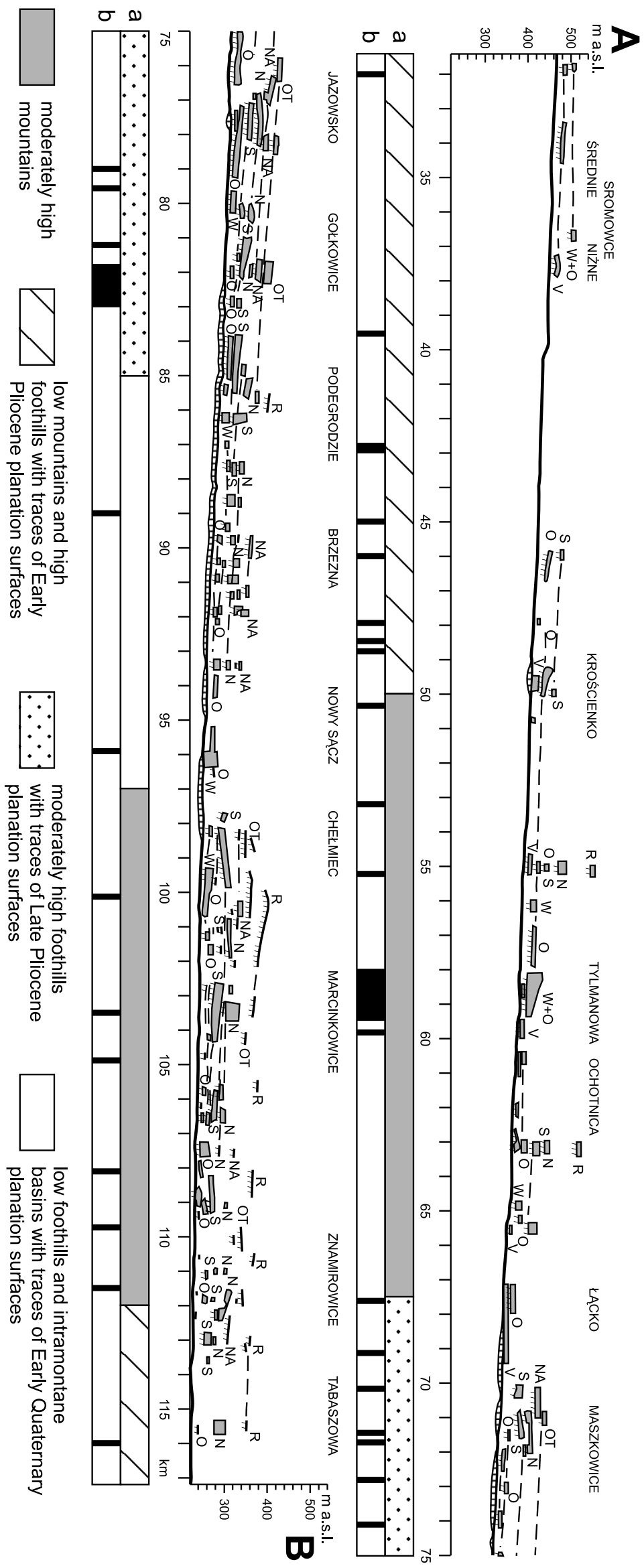




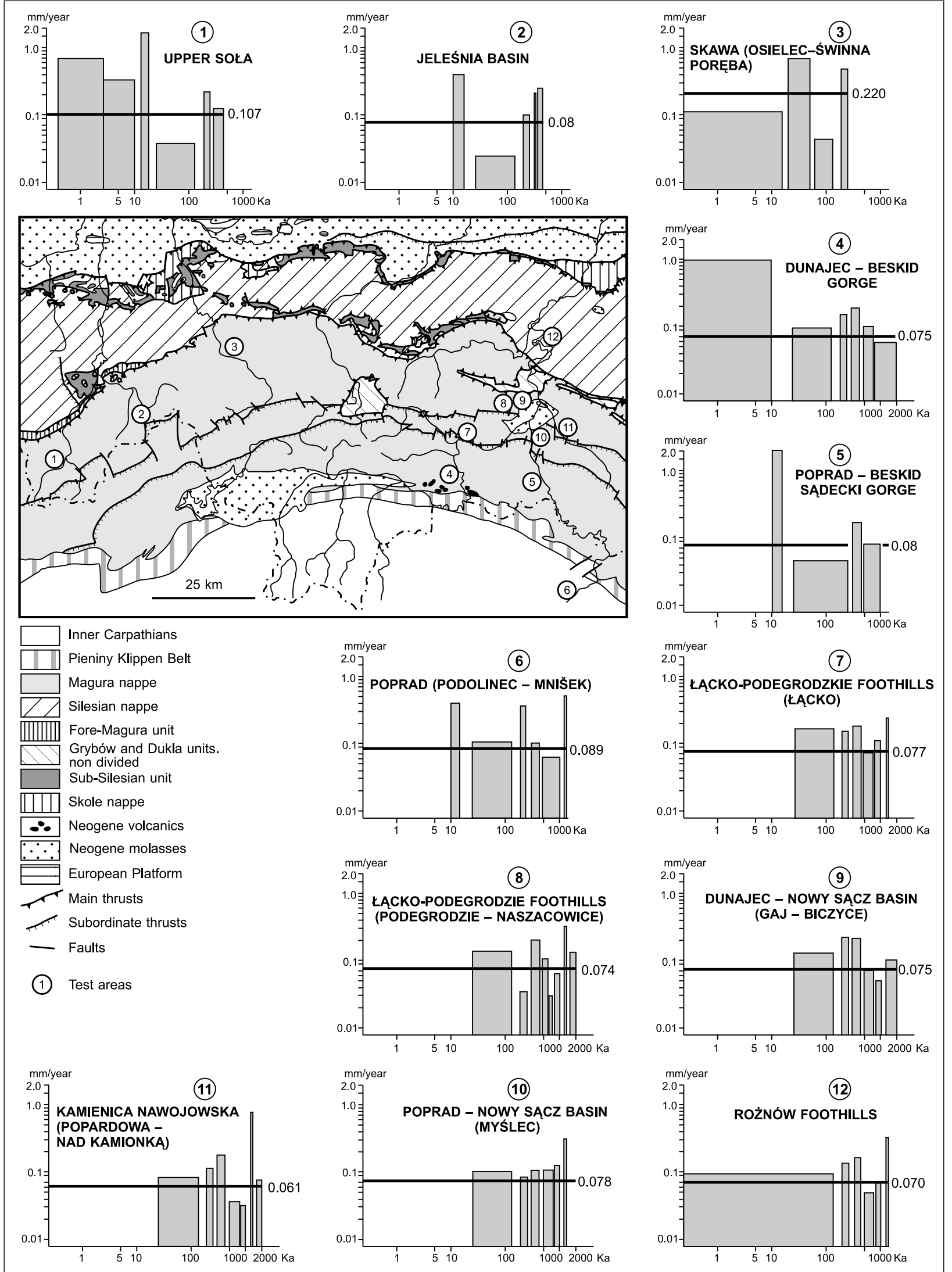

Fig. 13. Rates of fluvial downcutting into Quaternary straths at selected test areas in the Polish Outer Western Carpathians. Solid lines denote average rates of downcutting throughout the Quaternary. 
Carpathians as a whole (Zuchiewicz, 1991), including the Cromerian-Elsterian $1 / 2(0.15-0.21 \mathrm{~mm} / \mathrm{yr})$, Eemian-Early Weichselian $(0.18-0.40 \mathrm{~mm} / \mathrm{yr})$ and Late Glacial-Holocene $(0.2-2.0 \mathrm{~mm} / \mathrm{yr})$ time-spans. A word of caution should be added that the quoted rates are estimates of fluvial downcutting, and not uplift rates proper. Nevertheless, increased rates of downcutting into solid rocks (straths) can be used as proxy data for episodes of more vigorous uplift. These rates have been calculated as ratios of fluvial downcutting into solid bedrock, i.e. strath terraces of climatostratigraphicallyestimated age (the amount of dissection of fluvial covers proper being excluded as mostly climatically-controlled), to the age of downcutting which, usually, corresponds to the duration of individual interglacial stages.

The above mentioned episodes of increased fluvial downcutting (800-472 ka, 130-90 ka, and 15-0 ka BP) were particularly well marked in localised physiographic units, such as: the Beskid Sądecki Mts., Bieszczady Mts., and the northern margin of the Beskid Niski Mts. (cf. Figs. 10, 11, 14). The earliest episode coincides with one of global episodes of increased Quaternary tectonic mobility, distinguished by Kukla (1982) and Mörner (1994).

\subsection{Morphometric indices}

Some morphometric parametres (river-bed gradients, relief, valley floor width/valley floor height ratios, bifurcation ratios, the amount of 1st-order valleys, concavity ratios of the normalized river-bed profiles, physiographic parametres of small drainage basins, etc.) are indicative of young tectonic tendencies (cf. Keller and Pinter, 1996). For instance, abnormally high river-bed gradients and increased altitudes of valley divides, as well as unusually low values of valley widths and valley floor width/valley height ratios point to neotectonic uplift (cf. Zuchiewicz, 1987, 1995, and references therein; see also Fig. 14).

Taxonomic analysis of the links between the structure and character of valleys, ridges and landslide niches in the Polish segment of the Outer West Carpathians indicates young age of those ridge and valley patterns which are independent of bedrock structures (Jakubska, 1995). Detailed maps of relief energy and summit surfaces clearly show zones of increased resistance to erosion, as well as those associated with uplifted morphostructures. Relief energy values change from $50-100 \mathrm{~m}$ in the foothills areas and the Jasło-Sanok Depression to $>500 \mathrm{~m}$ in the highest-elevated regions of the Beskid Sạdecki Mts. (Zuchiewicz, 1995).

Another approach represents more or less successful attempts at digital processing of some morphometric parameters of small drainage basins (cf. Zuchiewicz, 1987, 1991) and time-series analysis of river-bed gradients or the valley floor width/valley height ratios (Zuchiewicz, 1995). The zones of abnormally high and low values of the first and second parameter, respectively, are aligned subparallel to the structural grain of the Outer Carpathians, their number increasing from the west to the east (Fig. 14). They also coincide to a large extent with the axes of neotectonically up- lifted structures detected on geomorphic maps (cf. Fig. 10). In the eastern segment of the Outer Carpathians some of uplifted structures are located at or in front of the present-day Carpathian frontal thrust, cutting it obliquely and passing into the Carpathian Foredeep (Fig. 14).

Relatively small widths of these structures $(15-25 \mathrm{~km})$ and their subparallel arrangement with respect to the strike of principal thrusts and imbricated slices led Zuchiewicz (1995, 1998) to hypothesize about Plio-Quaternary relaxation of remnant horizontal stresses, built up during the Neogene thrusting.

\subsection{Implications for structural development}

The presence of long and narrow zones that show alternately uplifting and subsiding tendencies in the eastern segment of the Outer Carpathians of Poland and are aligned subparallel to or crossing under small angles the structural grain of the region appears to exclude their purely isostatic origin. Uplift of these zones could have resulted from recent relaxation of horizontal stresses accumulated within the overthrust nappes. Such a mechanism explains: (a) manifestations of localised young uplift occurring along frontal thrusts of some imbricated slices, (b) the present-day configuration of $S_{\mathrm{hmax}}$ recorded by breakouts in wells that pierce through the flysch nappes and their substratum (cf. Jarosiński, 1998; see also discussion below), and revealed by focal mechanisms of the 1992-1993 Krynica earthquakes (Wiejacz, 1994; Dȩbski et al., 1997).

En echelon arrangement of theses zones, however, slightly different in the western and eastern parts of the study area (Figs. 14, 15) can also indicate young sinistral motions along the Kraków-Lubliniec fault in the substratum of the overthrust nappes. This hypothesis needs to be verified by future studies.

\section{Present-day picture}

Contemporary stress field from borehole breakouts

\subsection{Breakout data}

Directions of present-day stress have been investigated in fifteen deep wells located in the Polish part of the Outer Carpathians (Fig. 15) by means of borehole breakout analysis. Orientation of borehole cross section elongation due to breakouts was detected with 6-arm caliper tool and in some cases with borehole acoustic scanner tool (Jarosiński, 1998, 1999; Jarosiński and Zoback, 1998). Using these tools one can discriminate between stress-induced breakouts and technological "key seats". The analysed dipmeter data come from a depth greater than $1000 \mathrm{~m}$ (except for a few short intervals in shallow Carpathian nappes) and usually reach more than $3000 \mathrm{~m}$ depth. Fourteen of fifteen wells pierce through the Carpathian flysch nappes and penetrate the autochthonous complexes. Four of the wells reach the Precambrian metamorphic basement of the Upper Silesian Massif. 

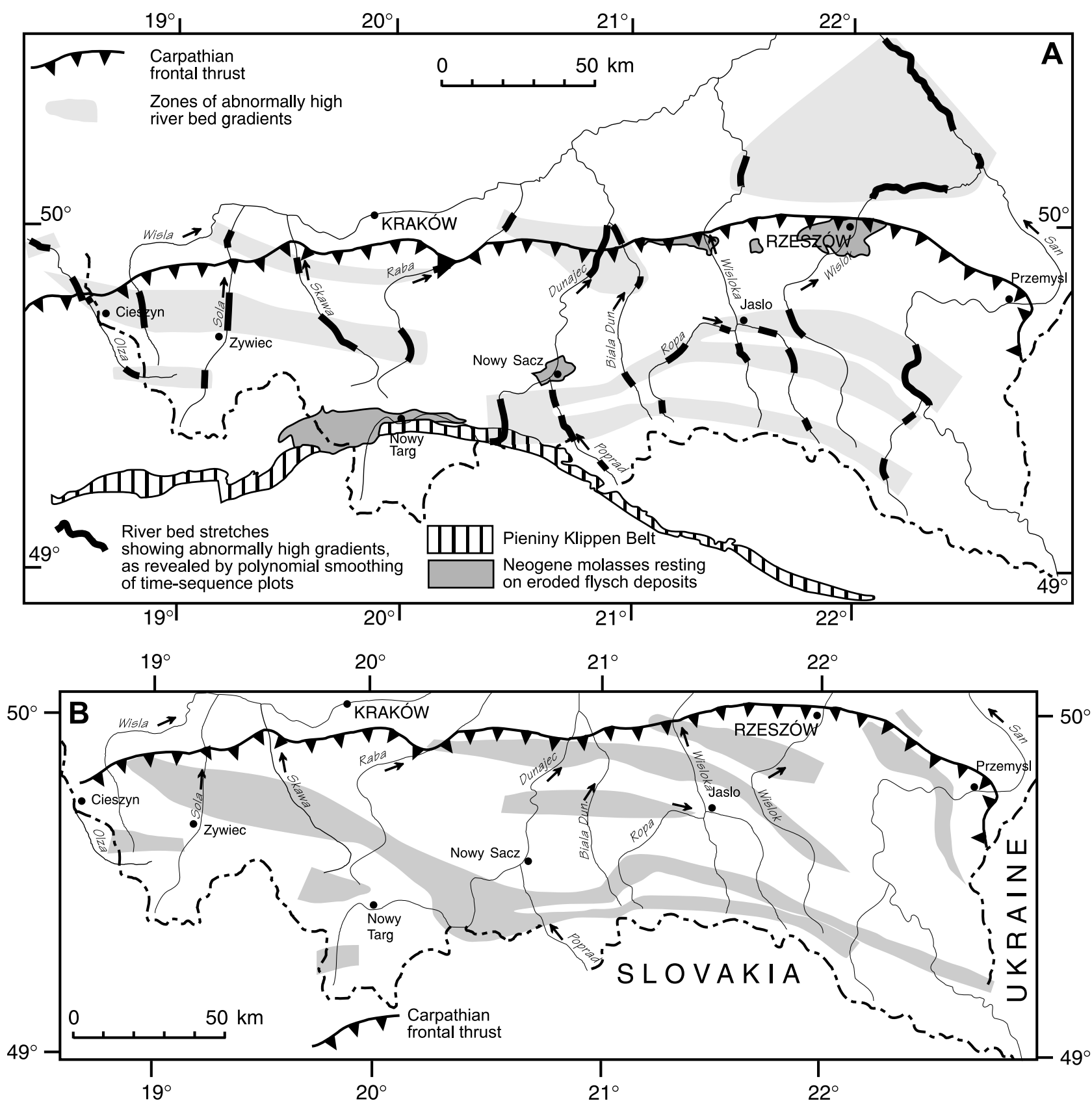

Fig. 14. Neotectonic tendencies in the Polish Outer Carpathians, indicated by selected morphometric indices: (A) - river-bed segments showing abnormally high gradients, (B) - distribution of minimum values of the valley floor width/valley floor height ratio, pointing to Recent uplift tendencies (redrawn from Zuchiewicz, 1995).

In the Carpathian flysch nappes, due to intensive tectonic deformations breakouts are irregularly shaped. Beneath them, in the autochthonous Miocene molasse complex, breakouts are usually scarce and rather shallow. The bestdeveloped breakouts were found in the autochthonous sedimentary and metamorphic rocks. In general, breakout data from the autochthonous basement are of higher quality than those from flysch nappes.

In the first approach breakout profile from each well was divided into intervals with relatively stable breakout orienta- tion. Next, for each depth section the weighted mean depth of breakouts, the total length of them and the quality of stress determination were computed, according to the standards of the World Stress Map Data Base (Zoback, 1992). Due to considerable differences in stress directions between the two Outer Carpathian domains with the Upper Silesian massif basement and Małopolska massif basement, the results are presented separately for these regions. 


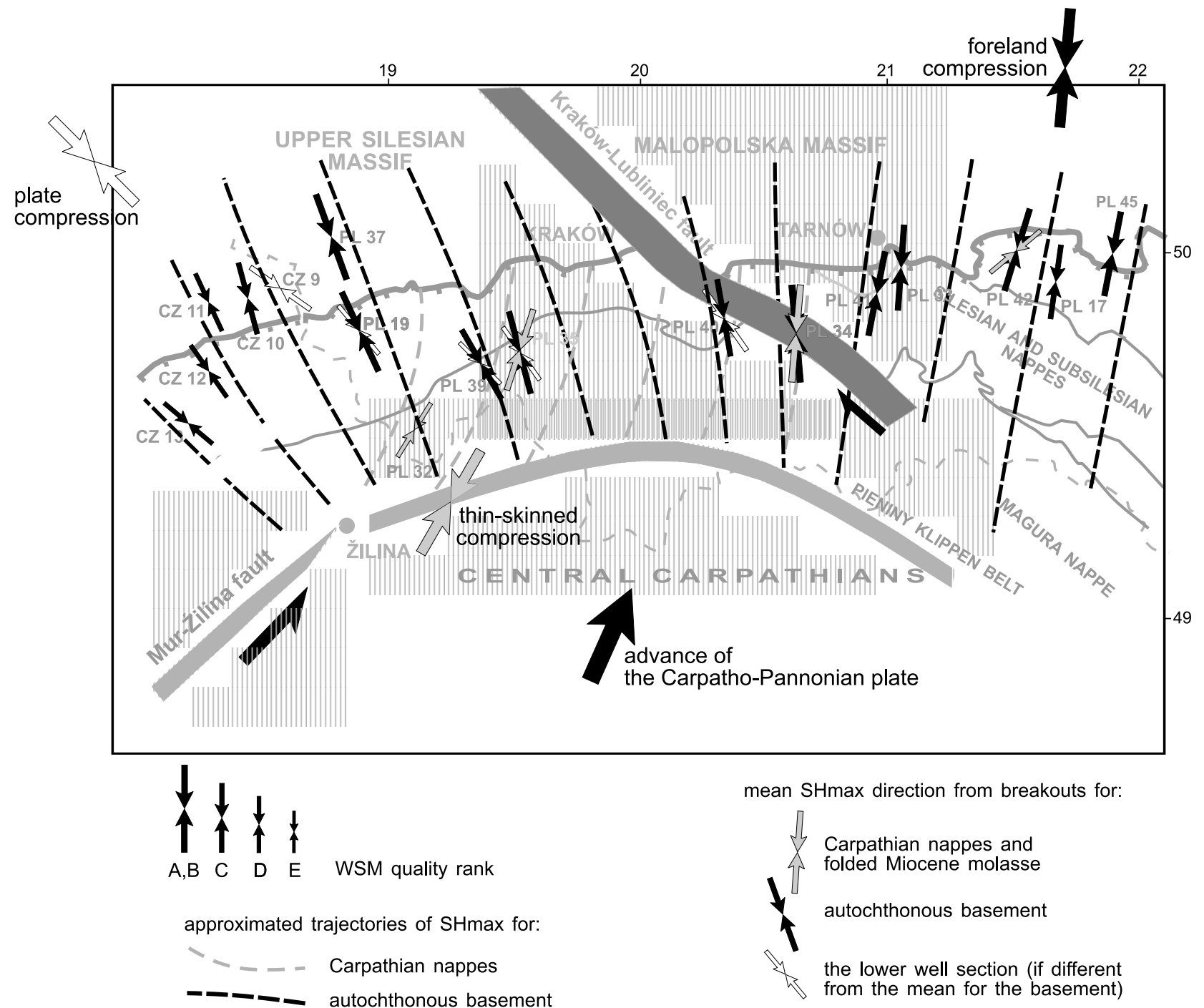

Fig. 15. Directions of $S_{\mathrm{hmax}}$ in the Polish Outer Carpathians and their basement. Trajectories of $S_{\mathrm{hmax}}$ are constructed separately for the Carpathian nappes and for their autochthonous basement. Where possible, trajectories for the lower geodynamic level are also drawn. Sizes of arrows express the World Stress Map quality rank, with A being the highest quality and E the lowest one.

\subsection{Present-day tectonic stress directions}

In the Upper Silesian massif domain, the most prominent feature is rotation of $\mathrm{S}_{\mathrm{Hmax}}$ directions with depth and also its distortion in plane. With increasing depth, $\mathrm{S}_{\mathrm{Hmax}}$ rotates systematically counterclockwise, showing quite consistent orientation within separate structural tiers (Fig. 15). For the flysch nappes, the mean NNE direction of $\mathrm{S}_{\mathrm{Hmax}}$ was determined. On the contrary, for the autochthonous basement, breakouts indicate in average $\mathrm{NNW}$-directed $\mathrm{S}_{\mathrm{Hmax}}$. In this basement the same sense of minor stress rotation is also detectable, thus in the deepest wellbore sections $\mathrm{S}_{\mathrm{Hmax}}$ turns to be ca. NW-orientated. Although the shift of stress directions across the Carpathian decollement was directly recorded only in the well PL 35, systematic differences in stress orientations between the nappes and their basement allow us to suspect stress partitioning along the floor thrust. Maximum stress rotation between the nappes and the deep- est metamorphic basement reaches $60^{\circ}$ (well PL 35). The degree of stress rotation decreases towards the margins of the Upper Silesian massif domain. In the Carpathian foredeep basin (well PL 37), no breakout rotation was observed in the long breakout profile, down to a depth of $4 \mathrm{~km}$.

In the Małopolska massif domain, stress directions were determined only beneath the flysch nappes (Fig. 15). Here, orientation of $\mathrm{S}_{\mathrm{Hmax}}$ is more stable than in the Upper Silesian massif domain. For the autochthonous complex, the mean $\mathrm{S}_{\mathrm{Hmax}}$ direction is limited to the narrow range of azimuths of $1-19^{\circ} \mathrm{NE}$. Nevertheless, minor clockwise rotation of $\mathrm{S}_{\mathrm{Hmax}}$ (in the range of error bars) from the north in unfolded Miocene molasses to NNE in the deeper basement can be detected. Considerable deviation of $\mathrm{S}_{\mathrm{Hmax}}$ orientation towards the NE occurred only within folded Miocene molasse, directly below the floor thrust of the Carpathian nappes (well PL 42). 


\subsection{Recent geodynamic conditions}

In the autochthonous complex of the Outer Carpathians, stress trajectories create radial pattern with $\mathrm{S}_{\mathrm{Hmax}}$ trajectories approximately perpendicular to the suture zone located at the Pieniny Klippen Belt (Fig. 15). The mean $\mathrm{S}_{\mathrm{Hmax}}$ directions change from NNE for the Małopolska Massif domain to NNW in the Upper Silesian Massif domain. Farther to the west, within the Bohemian Massif basement, breakout data suggest consequent trend of stress distortion towards the NW (Peška, 1992) (Fig. 15). The other characteristic feature of the stress field is $\mathrm{S}_{\mathrm{Hmax}}$ rotation with depth and possible stress partitioning between the flysch nappes and their basement.

Both phenomena, $\mathrm{S}_{\mathrm{Hmax}}$ rotation with depth and its distortion in plane, might be explained assuming interaction between three main factors:

1) plate-scale stress, which per analogies to the West European stress province is assumed to be NW-orientated (Müller at al., 1992);

2) tectonic push of the ALCAPA unit towards the NE, which is suggested by left-lateral strike-slip motion along the Mür-Žilina fault zone (Tomek, 1988) and by the first results of GPS measurements (Hefty, 1998);

3) passive buoyancy forces due to the structure of the orogen that are assumed to act perpendicularly to the trend of the arc. Due to lack of deep crustal roots beneath the Carpathians this factor is not expected to produce significant stresses.

From these assumptions the following geodynamic setting can be proposed. The ALCAPA unit advancing towards the NE pushes the Carpathian nappes, exerting NE- to NNEorientated thin-skinned compression in the allochthonous cover of the Upper Silesian massif. Similar direction of compression can be expected in the nappes above the Małopolska massif. In contrary, the basement of the Upper Silesian massif shows significantly different, NNW or NW direction of $\mathrm{S}_{\mathrm{Hmax}}$, which can be related to the European plate compression. Such stress partitioning in the foreland plate requires weak, low friction contact between plates in the western segment of Carpathian suture. In the autochthonous sedimentary cover of the Małopolska massif basement, the N-S to NNE orientation of $\mathrm{S}_{\mathrm{Hmax}}$ suggests that the basement is partially affected by the ALCAPA's tectonic push. Similar, NS-directed $\mathrm{S}_{\mathrm{Hmax}}$ was determined for the distal part of the foreland plate (Jarosiński, 2000), what excludes the passive buoyancy forces as the main source of stress deviation from plate direction. Thus, for the eastern segment of the suture resistive contact between plates is likely. According to the results of deep seismic sounding (Tomek, 1993), the Carpathian slab is steeper in the eastern segment than in the western one, what can be one of the reasons why the plate in the eastern segment resists stronger against horizontal tectonic forces.
Seismicity and recent crustal movements

Within the Polish segment of the Outer Carpathians, recent seismicity is confined to some strike-slip faults (Prochazková et al., 1978). Magnitudes of historical earthquakes do not exceed 5.0 on the Richer scale (Pagaczewski, 1972; Prochazková et al., 1978). Focal solutions are available only for the sequences of earthquakes that occurred in 1992 and 1993 in the vicinity of Krynica (Fig. 1). The focal depths were probably less than $5 \mathrm{~km}$ (Dębski et al., 1997), and the focal solutions point to either compressional stress arrangement with $\sigma_{1}$ trending NNW (Wiejacz, 1994), or to both strike-slip (indicating the N-S orientation of $\sigma_{1}$ ) and extensional stress pattern (Dȩbski et al., 1997).

Geodetically measured vertical crustal movements range from 0 to $+1 \mathrm{~mm} / \mathrm{yr}$ (e.g. Wyrzykowski, 1985; Nikonov et al., 1987). Results of recent GPS campaigns indicate a NNE direction of horizontal motions in the Polish Outer Carpathians (Hefty, 1998).

\section{Conclusions}

The presented pieces of structural evidence imply that during the Late Neogene (post-Pannonian?) times structural development of the Polish segment of the Outer Carpathians was largely controlled by normal faulting. This interpretation is corroborated by geomorphic data indicative of en block uplift of some near-surface portions of the flysch cover in the western part of the belt. However, there is no unequivocal evidence to decide whether the faulting was due to successive phases of alternating N-S and E-W extension or owing to one or more phases of multidirectional extension.

Moreover, the geomorphic data from the medial and eastern parts of the belt and fractured pebbles in the Orava Basin suggest the occurrence of compressional stress regime during Late Neogene times. It follows that during the Late Neogene the stress arrangement was differentiated depending on time and the position in the belt. We find it interesting that the stress arrangement could have been so differentiated during such a short period of time. Usually in tectonic reconstructions, tectonic phases are of longer duration and during particular phases stress arrangement is uniform within the studied area.

The Pliocene-Quaternary tectonic mobility of the Polish Outer Carpathians was relatively weak and mostly of thinskinned character. Normal faults were formed on the margins of intramontane basins and in the western part of the belt. Rates of uplift of individual structures was variable and the amount of uplift was the greatest in the Late Pliocene and Early Quaternary times. Geomorphologically-detected zones of uplift are relatively narrow and arranged subparallel or under small angle in respect to the strike of principal thrusts and frontal parts of large slices. Such an arrangement is interpreted as resulting from the steepening of frontal thrusts due to horizontal compression within the overthrust flysch nappes. This hypothesis is confirmed by the results 
of recent break-out and GPS studies, as well as focal solutions of some Outer Carpathian earthquakes. En echelon pattern of the uplifted zones, slightly different in the western and eastern portions of the belt can also suggest young sinistral motions along the Kraków-Lubliniec fault zone beneath the overthrust nappes. The last conjecture, however, requires verification by future geological and geodetic studies.

The recent stress pattern indicates that the ALCAPA unit advancing towards the NE pushes the Carpathian nappes, exerting NE-to NNE-orientated thin-skinned compression in the allochthonous cover of the Upper Silesian massif. Similar direction of compression can be expected in the nappes above the Małopolska massif. On the other hand, the basement of the Upper Silesian massif shows significantly different, NNW or NW directions of $\mathrm{S}_{\mathrm{H} \max }$, which can be related to the European plate compression.

Acknowledgements. We would like to acknowledge helpful comments by M. Kovač, P. Krzywiec, and S. Cloetingh that helped to improve the original version of the paper.

\section{References}

Aleksandrowski, P.: Structure of the Mt. Babia Góra region, Magura nappe, Western Outer Carpathians: An interference of West and East Carpathian fold trends (in Polish with English summary). Ann. Soc. Geol. Polon., 55, 375-422, 1985.

Alexandrowicz, S. W.: Miocene tectonics in the Upper Silesian Basin (in Polish with English summary). Acta Geol. Polon., 14, 175-231, 1964.

Bada, G.: Cenozoic stress field evolution in the Pannonian basin and surrounding orogens - Inferences from kinematic indicators and finite element modelling. Vrije Universiteit, Amsterdam, 1-204, 1999.

Baumgart-Kotarba, M.: The geomorphological evolution of the intramontane Orawa Basin associated with neotectonic movements (Polish Carpathians) (in Polish with English summary). Studia Geomorph. Carpatho-Balcan., 25-26, 3-28, 1991-92.

Baumgart-Kotarba, M.: On origin and age of the Orava Basin, West Carpathians. Studia Geomorph. Carpatho-Balcan., 30, 101-116, 1996.

Birkenmajer, K.: Geological guidebook of the Pieniny Klippen Belt (in Polish). Publ. House Wyd. Geol., Warszawa, 235 pp, 1979.

Birkenmajer, K.: Major strike-slip faults of the Pieniny Klippen Belt and the Tertiary rotation of the Carpathians. Publs. Inst. Geophys. Pol. Acad. Sci., A-16 (175), 101-115, 1985.

Bull, W. B.: Stream-terrace genesis: implications for soil development. Geomorphology, 3, 351-367, 1990.

Burbank, D. W., Leland, J., Fielding, E., Anderson, R. S., Brozovic, N., Reid, M. R., and Duncan, C.: Bedrock incision, rock uplift, and threshold hillslopes in the northwestern Himalayas. Nature, 379, 505-510, 1996.

Csontos, L.: Tertiary tectonic evolution of the Intra-Carpathian area: a review. Acta Vulcanologica, 7, 1-13, 1995.

Csontos, L., Horvath, F., and Kovač, M.: Tertiary evolution of the Intra-Carpathian area: a model. Tectonophysics, 208, 221-241, 1992.

Decker, K., Nescieruk, P., Reiter, F., Rubinkiewicz, J., Ryłko, W., and Tokarski, A. K.: Heteroaxial shortening, strike-slip faulting and displacement transfer in the Polish Carpathians. Przegląd Geologiczny, 45, 1070-1071, 1997.
Decker, K., Tokarski, A. K., Jankowski, L., Kopciowski, R., Nescieruk, P., Rauch, M., and Świerczewska, A.: Structural development of Polish segment of the Outer Carpathians (eastern part). 5th Carpathian Tectonic Workshop, Poprad-Szymbark, 59th June 1999, Kraków, 26-29, 1999.

Dębski, W., Guterch, B., Lewandowska, and H., Labak, P.: Earthquake sequences in the Krynica region, Western Carpathians, 1992-1993. Acta Geophys. Polon., 45, 255-290, 1997.

Fodor, L., Csontos, L., Bada, G., Györfi, I., and Benkovics, L.: Tertiary tectonic evolution of the Pannonian Basin system and neighbouring orogens: a new synthesis of palaeostress data, in: Durand, B., Jolivet, L., Horvath, F., and Seranne, M. (Eds.): The Mediterranean Basins: Tertiary Extension within the Alpine Orogen. Geol. Soc. Spec. Publs., 156, 295-334, 1999.

Gerlach, T., Koszarski, L., and Koszarski, A.: Stop 23. ŁężanyJabłonica-Niebylec-Krasna-Weglówka. Selected problems of geomorphology and Quaternary along the Dukla Pass-Rzeszów transect, in: Poprawa, D.(Ed.): Guide to Excursion 5, XIII Congress, Carpatho-Balkan Geol. Assoc., Cracow, Poland 1985, Geol. Inst., Kraków, 96-110, 1985.

Hefty, J.: Estimation of site velocities from CEGRN GPS campaigns referred to CERGOP reference frame. Publ. Warsaw Techn. Univ., Inst. Geodesy and Geodetic Astronomy, 9 (39), 67-79, 1998.

Henkiel, A.: The origin of the relief of the Polish Flysch Carpathians (in Polish with English summary). Annales UMCS, Sec. B 32-33 (1), 1-35, 1977-78.

Henkiel, A., Pȩkala, K., and Poprawa, D.: Excursion C. Geomorphology, Quaternary geology and selected problems of engineering geology and hydrogeology of the Przemyśl Carpathians and their foreland (in Polish), in: Kotlarczyk, J. (Ed.): Przewodnik LIX Zjazdu Pol. Tow. Geol., Przemyśl, 16-18 IX 1988, Wyd. AGH, Kraków, 191-258, 1988.

Hurai, V., Świerczewska, A., Marko, F., Tokarski, A. K., and Hrušecký, I.: Paleofluid temperatures and pressures in Tertiary accretionary prism of the Western Carpathians. Slovak Geol. Mag., 6, 194-197, 2000.

Jakubska, O.: Tectonic features of young structural relief of the Western Carpathians, South Poland. Folia Quaternaria, 66, 123130, 1995.

Jarosiński, M.: Contemporary stress field distortion in the Polish part of the Western Outer Carpathians and their basement. Tectonophysics, 297, 91-119, 1998.

Jarosiński, M.: Studies of recent crustal stresses in deep boreholes in Poland by wellbore breakouts (in Polish). Instrukcje i Metody Badań Geologicznych, 56, 1-147, 1999.

Jarosiński, M.: Neotectonic and present-day reactivation of the Carpathian orogen and its foreland as inferred from contemporary stress, intraplate motions and Quarternary tectonic features. Abstracts, PANCARDI 2000, 1.-3.10.2000, Croatia, Vijesti Hrvatskoga Geoloskog Drustva, 37 (3), 55-56, 2000.

Jarosiński, M. and Zoback, M. D.: Comparison of six-arm caliper and borehole televiewer data for detection of stress induced wellbore breakouts: Application to six wells in the Polish Carpathians. Stanford Rock Physics \& Borehole Geophysics, 64 (F8), 135, 1998.

Keller, E. A. and Pinter, N.: Active Tectonics. Earthquakes, Uplift, and Landscape. Prentice Hall, Upper Saddle Valley, New Jersey, 338 pp, 1996.

Klimaszewski, M.: Relief of the Polish Tatra Mountains (in Polish). Publ. House PWN, Warszawa, 668 pp, 1988. 
Kopciowski, R., Tokarski, A. K., Świerczewska, A., and Rauch, M.: Early (Maastrichtian-Paleocene) synsedimentary thrusting within Siary slice (Magura nappe). 5th Carpathian Tectonic Workshop, Poprad-Szymbark, 5-9th June 1999, Kraków, 34-35, 1999.

Koszarski, A. and Koszarski, L.: Stop 39. Łężany. Tectonics of the Jasło-Sanok Depression and its relation to the Quaternary events, in: Koszarski, L. (Ed.): Geology of the Middle Carpathians and the Carpathians Foredeep. Guide to Excursion 3, XIII Congress Carpatho-Balkan Geol. Assoc., Cracow, Poland 1985. Geol. Inst., Warszawa, 176-178, 1985.

Kotlarczyk, J.: Evolution of the Carpathian tectogene in the Miocene, in: Kotlarczyk, J.(Ed.): Geotraverse KrakówBaranów-Rzeszów-Przemyśl-Ustrzyki Dolne-Komańcza-Dukla. Guide to Excursion 4, XIIIth Congress, Carpatho-Balkan Geol. Assoc., Geol. Inst., Warszawa, 21-32, 1985.

Kotulova, J., Biron, A., and Sotak, J.: Organic and illite-smectite diagenesis of the Central Carpathians Paleogene basin: implications for thermal history. Abstracts, XVI Congress, CarpathoBalkan Geol. Assoc., Vienna, Aug. 30th - Sept. 2nd, 1998, Vienna, p. 293, 1998.

Kovač, M. and Márton, E.: To rotate or not to rotate: Palinspastic reconstruction of the Carpatho-Pannonian area during the Miocene. Slovak Geol. Mag., 42, 75-85, 1998.

Krzywiec, P. and Zuchiewicz, W.: Late Neogene-Quaternary uplift of the Polish Outer Carpathians inferred from geomorphic and seismotectonic data. Abstract Suppl. 2, Terra Nova, 5, 20, 1993.

Kukla, J.: Late Cenozoic land-sea correlations. XI INQUA Congress - Moscow, Abstracts, 1, 175, 1982.

Kukulak, J.: Orientation of joints and faults in the SE part of the Orawa Depression (in Polish with English summary). Przegląd Geologiczny, 47, 1021-1026, 1999.

Kuśmierek, J.: Outline of geodynamics of Central Carpathian oil basin (in Polish with English summary). Pr. Geol. Kom. Nauk Geol. PAN w Krakowie, 135, 1-85, 1990.

Márton, E., Mastella, L., and Tokarski, A. K.: Large counterclockwise rotation of the Inner West Carpathian Paleogene Flysch evidence from paleomagnetic investigations of the Podhale Flysch (Poland). Phys. Chem. Earth, (A), 24(8), 645-649, 1999a.

Márton, E., Tokarski, A. K., and Galicia T. Group: Northward migration of north ALCAPA boundary during Tertiary accretion of the Outer Carpathians - paleomagnetic approach. Romanian J. Tect. Reg. Geol., 77 (1), 22, 1999b.

Márton, E., Rauch, M., and Tokarski, A. K.: A pilot paleomagnetic study of the Polish segment of the Carpathian Foredeep. Biuletyn Państwowego Instytutu Geologicznego, 387, 140-141, 1999c.

Mörner, N.-A.: Neotectonics in new perspectives. Bull. INQUA Neotectonics Comm., 17, 63-65, 1994.

Müller, B., Zoback, M. L., Fuchs, K., Mastin, L., Gregersen, S., Pavoni, N., Stephansson, O., and Ljunggren, C.: Regional patterns of tectonic stress in Europe. J. Geoph. Research, 97 (B8), 11 783-11 803, 1992.

Nemčok, M., Houghton, J. J., and Coward, M. P.: Strain partitioning along the western margin of the Carpathians. Tectonophysics, 292, 119-143, 1998.

Niedzielski, H.: Tectonic origin of the eastern part of the valley of Nowy Targ (in Polish with English summary). Ann. Soc. Geol. Polon., 41, 397-408, 1971.

Nikonov, A. A., Skryl, V. A., and Lisovets, A. G.: A new version of the map of recent vertical crustal movements in the CarpathoBalkan region based on the collocation methods. J. Geodyn., 8, 337-345, 1987.
Oszast, J. and Stuchlik, L.: The Neogene vegetation of the Podhale (West Carpathians, Poland) (in Polish with English summary). Acta Palaeobot., 18, 45-122, 1987.

Oszczypko, N.: The Miocene dynamics of the Carpathian Foredeep in Poland (in Polish with English summary). Przegląd Geologiczny, 44, 1007-1018, 1996.

Oszczypko, N.: The Western Carpathian Foredeep - development of the foreland basin in front of the accretionary wedge and its burial history (Poland). Geol. Carpathica, 49, 415-431, 1998.

Oszczypko, N., Olszewska, B., Ślęzak, J., and Strzȩpka, J.: Miocene marine and brackish deposits of the Nowy Sa̧cz basin (Polish Western Carpathians) - New lithostratigraphic and biostratigraphic standards. Bull. Polish Acad. Sci., Earth Sci., 40, 83 96, 1992

Oszczypko, N. and Tomaś, A.: Tectonic evolution of marginal part of the Polish Flysch Carpathians in the Middle Miocene. Kwartalnik Geologiczny, 29, 109-128, 1985.

Oszczypko, N., Tomaś A., and Zuchiewicz, W.: Compaction of Miocene molasses and neotectonic mobility of the Polish Carpathian foothills (in Polish with English summary). Przegląd Geologiczny, 41, 411-416, 1993.

Oszczypko, N., Zając, R., Garlicka, I., Menčik, E., Dvorak, J., and Matejovska, O.: Geological map of the substratum of the Tertiary of the Western Outer Carpathians and their foreland, 1:500 000, in: Poprawa, D. and Nemčok, J. (Eds.): Geological Atlas of the Western Outer Carpathians and their Foreland. Pa nstwowy Instytut Geologiczny, Warszawa, 1989.

Pagaczewski, J.: Catalogue of earthquakes in Poland in 1000-1970 years (in Polish with English summary). Materiały i Prace Instytutu Geofizyki PAN, 51, 3-36, 1972.

Peška, P.: Stress indications in the Bohemian Massif: reinterpretation of the borehole televiewer data. Studia Geoph. et Geodaet., 4, 307-324, 1992.

Pomianowski, P.: Structure of the Orava Basin in the light of selected geophysical data (in Polish with English summary). Ann. Soc. Geol. Polon., 64, 67-80, 1995.

Prochazková, D., Brouček, I., Guterch, B., and Lewandowska-Marciniak, H.: Map and list of the maximum observed macroseismic intensities in Czechoslovakia and Poland. Publs. Inst. Geophys. Pol. Acad. Sci., B-3 (122), 1-75, 1978.

Rubinkiewicz, J.: Development of fault pattern in the Silesian nappe: Eastern Outer Carpathians, Poland. Geol. Quart., 44: 391-403, 2000.

Sawicki, L.: Die jüngeren Krustenbewegungen in den Karpathen (in Polish with German summary). Kosmos, 34, 361-400, 1909.

Schumm, S. A.: Alluvial river response to active tectonics, in: Wallace, R. E. (Ed.): Active Tectonics. Studies in Geophysics, Natl. Acad. Press, Washington, 80-94, 1986.

Sikora, W. and Wieser, T.: Pyroclastic rocks in the Neogene strata of the intramontane Orava-Nowy Targ basin (in Polish). Kwartalnik Geologiczny, 18, 441-443, 1974.

Starkel, L.: The Outer Carpathians (in Polish), in: Klimaszewski, M. (Ed.): Geomorphology of Poland, 1. Publ. House PWN, Warszawa, 52-115, 1972.

Starkel, L. (Ed.). Geomorphological map of Poland, 1: 500000 (in Polish with English summary). IGiPZ PAN, Warszawa, 1980.

Starkel, L.: Controversial opinions on the role of tectonic movements and climatic changes in the Quaternary evolution of the Polish Carpathians. Studia Geomorph. Carpatho-Balcan., 19, 45-60, 1985 .

Starkel, L.: Relief, in: Dynowska, I. and Maciejewski, M. (Eds.): Upper Vistula drainage basin, Part I (in Polish). Publ. House 
PWN, Warszawa-Kraków, 42-54, 1991.

Starkel, L.: The glacial-interglacial cycle in the evolution of the Vistula River basin (in Polish with English summary), in: Kostrzewski, A.(Ed.): Origin, lithology and stratigraphy of Quaternary sediments II. Publ. HouseWyd. Nauk. UAM, ser. Geografia, 57, 297-305, 1996.

Świerczewska, A. and Tokarski, A. K.: Deformation bands and the history of folding in the Magura nappe, Western Outer Carpathians (Poland). Tectonophysics, 297, 73-90, 1998.

Şengör, C. M. A., Görür, N., and Şaroglu, F.: Strike-slip faulting and related basin formation in zones of tectonic escape: Turkey as a case study. Spec. Publ. Soc. Econ. Paleont. Miner., 37, 227-264, 1985.

Tokarski, A. K.: On Quaternary fault and jointing in Nowy Sạcz Basin (Outer Western Carpathians, Poland) (in Polish with English summary). Ann. Soc. Geol. Polon., 48, 509-516, 1978.

Tokarski, A. K. and Świerczewska, A.: History of folding in the Magura nappe, Outer Carpathians, Poland, in: Rossmanith, H.-P. (Ed.): Mechanics of Jointed and Faulted Rock. A. A. Balkema, Rotterdam, 125-130, 1998.

Tokarski, A. K. and Zuchiewicz, W.: Fractured clasts in the Domański Wierch series: Contribution to structural evolution of the Orava Basin (Carpathians, Poland) during Neogene through Quaternary times (in Polish with English summary). Przegląd Geologiczny, 46, 62-66, 1998.

Tomek, C.: Geophysical investigation of the Alpine-Carpathian Arc, in: M. Rakus, J. Dercourt, A.E.M. Nairn, Evolution of the Northern Margin of Tethys 1, Occ. Publ. ESRI, New Series, 3, 167-199, 1988.

Tomek, C.: Deep crustal structure beneath the central and inner Western Carpathians. Tectonophysics, 226, 417-431, 1993.

Uhlig, V.: Bau und Bild der Karpathen. Wien, 261 pp., 1903.

Wiejacz, P.: An attemp to determine tectonic stress pattern in Poland. Acta Geophys. Polon., 42, 169-176, 1994.

Wójcik, A.: Terrace systems in the Koszarawa drainage basin and their relation to tectonic movements in the Beskid Zywiecki Mts. (in Polish with English summary). Studia Geomorph. CarpathoBalcan., 22, 21-45, 1989.

Wójcik, A. and Jugowiec, M.: The youngest members of the folded Miocene in the Andrychów region (Southern Poland). Przegląd Geologiczny, 46, 763-770, 1998.

Wójcik, A., Szydło, A., Marciniec, P., and Nescieruk, P.: The folded Miocene of the Andrychów region. Biuletyn Państwowego Insty- tutu Geologicznego, 387, 191-195, 1999.

Wyrzykowski, T.: Map of recent vertical crustal movements on the territory of Poland (in Polish with English summary). Inst. Geod. Kartogr., Warszawa, 1985.

Zastawniak, E.: Pliocene leaf flora from Domański Wierch (Western Carpathians, Poland). Acta Palaeobot., 13, 1-73, 1972.

Zoback, M. L.: First- and second-order patterns of stress in the lithosphere: the World Stress Map Project. J. Geoph. Research., 97(B8), 11 703-11 728, 1992.

Zoetemeijer, R., Tomek, Ç., and Cloetingh, S. A. P. L.: Flexural expression of European continental lithosphere under the western outer Carpathians. Tectonics, 18, 843-861, 1999.

Zuchiewicz, W.: The Late Neogene-Quaternary tectonic mobility of the Polish West Carpathians. A case study of the Dunajec drainage basin. Ann. Soc. Geol. Polon., 54, 133-189, 1984.

Zuchiewicz, W.: Evolution of the eastern Beskid Niski Mts. and morphotectonics of the Polish Carpathians. Zesz. Nauk. AGH, Geologia, 13 (3-4), 3-167, Kraków, 1987.

Zuchiewicz, W.: On different approaches to neotectonics: A Polish Carpathians example. Episodes, 14, 116-124, 1991.

Zuchiewicz, W.: Selected aspects of neotectonics of the Polish Carpathians. Folia Quaternaria, 66, 145-204, 1995.

Zuchiewicz, W.: Quaternary tectonics of the Outer West Carpathians, Poland. Tectonophysics, 297, 121-132, 1998.

Żaba, J.: The structural evolution of Lower Palaeozoic succession in the Upper Silesia Block and Małopolska Block border zone (Southern Poland) (in Polish with English summary). Prace Państwowego Instytutu Geologicznego, 166, 1-162, 1999.

Żytko, K.: Remarks on Palaeogene tectonic movements in the Outer Carpathians (in Polish). Kwartalnik Geologiczny, 21, 939-940, 1977.

Żytko, K.: Symmetrical pattern of the Late Alpine features of the Northern Carpathian basement, their foreland and hinterland, orogen and craton suture (in Polish with English summary). Prace Państwowego Instytutu Geologicznego, 168, 165194, 1999.

Żytko, K., Zając, R., Gucik, S., Ryłko, W., Oszczypko, N., Garlicka, I., Nemčok, J., Eliaś, M., Menčik, E., and Stranik, Z.: Map of the tectonic elements of the Western Outer Carpathians and their foreland, 1:500 000, in: Poprawa, D. and Nemčok, J. (Eds.): Geological Atlas of the Western Outer Carpathians and their Foreland. Panstwowy Instytut Geologiczny, Warszawa, 1989. 